\title{
The Effect of Biodegradable Waste Pyrolysis Temperatures on Selected Biochar Properties
}

\author{
Katarzyna Wystalska *(D) and Anna Kwarciak-Kozłowska \\ Faculty of Infrastructure and Environment, Czestochowa University of Technology, 42-200 Czestochowa, Poland; \\ anna.kwarciak@pcz.pl \\ * Correspondence: katarzyna.wystalska@pcz.pl
}

Citation: Wystalska, K.;

Kwarciak-Kozłowska, A. The Effect of Biodegradable Waste Pyrolysis Temperatures on Selected Biochar Properties. Materials 2021, 14, 1644. https://doi.org/10.3390/ma14071644

Academic Editor: Alain Celzard

Received: 22 February 2021

Accepted: 24 March 2021

Published: 27 March 2021

Publisher's Note: MDPI stays neutral with regard to jurisdictional claims in published maps and institutional affiliations.

Copyright: (c) 2021 by the authors. Licensee MDPI, Basel, Switzerland. This article is an open access article distributed under the terms and conditions of the Creative Commons Attribution (CC BY) license (https:// creativecommons.org/licenses/by/ $4.0 /)$.
Abstract: Biochars produced during biodegradable waste pyrolysis are products with a wide range of environmental applications. The effect of impact biochars depends on their properties which determine the course of specific processes. The main aim of the study was to investigate the effect of pyrolysis temperature on selected properties of biochar produced from various plant wastes (beech wood chips, walnut shells, wheat-rye straw), the valorization of which is of key importance for the implementation of the circular economy. Biochars were produced at temperatures of: $400{ }^{\circ} \mathrm{C}, 500{ }^{\circ} \mathrm{C}$, $600{ }^{\circ} \mathrm{C}$ and $700{ }^{\circ} \mathrm{C}$ in a nitrogen atmosphere. An increase in the pyrolysis temperature caused a drop in the biochar production yield. As the temperature increased, higher carbon content and lower hydrogen content could be seen in the products obtained. An increase in the $\mathrm{pH}$ and total organic carbon (TOC) values also found. The influence of temperature on ash content, observed in the case of BWS (biochar from walnut shell) and BWRS (biochar from wheat and rye straw), did not occur in the case of BWC (biochar from beech wood chips). Another parameter that demonstrated a growing tendency with increasing temperature was the BET specific surface area (except for biochars from wheat and rye straw). An increase in pyrolysis temperature caused a decrease in the diversity and density of the surface functional groups of biochars. The influence of the type of precursor used in the production of biochar on the presence of surface functional groups was demonstrated. The presence of intense stretching vibrations of $\mathrm{C}-\mathrm{O}$ bonds, having a potential impact on the sorption capacity of biochars, was determined in the FTIR spectra of BWC600 and BWC700 biochars, this feature, combined with the large BET surface area, may affect the sorption potential of these biochars. The presence of this type of high-intensity vibrations was also observed in the spectra of biochar BWRS600 and BWRS700. This can compensate for the low BET surface value and play an important role when using these biochars in sorption processes for organic and inorganic compounds.

Keywords: biodegradable waste; biochar; circular economy; pyrolysis temperature

\section{Introduction}

One of the challenges of the circular economy, i.e., an economy which aims, among others, at minimizing the quantities of waste generated, is the capacity of recovering useful products from waste materials. Such a solution requires not only systemic transformations and changes in management, but also the development of new environment-friendly waste treatment technologies. This manner of waste handling makes it possible to reduce the use of natural resources and to generate energy and new materials. These actions are very significant for climate change mitigation and are therefore increasingly desirable for society.

Residues from agri-food production or wastes generated in the municipal sector continue to pose a significant problem for the managers of the economy regarding the choice of a method for their disposal. Appropriate waste management would not only eliminate their adverse environmental impacts (among others, greenhouse gas emissions, water and soil pollutants), but also, in line with the current expectations, enable new value added products to be derived [1-5]. These products could be incorporated into the environmental cycle while, at the same time, closing the nutrient cycles [6]. 
Waste treatment in the pyrolysis process corresponds well with the circular economy model. Pyrolysis is a well-known process that has long been used to treat different types of materials [7]. At present, it is increasingly often used to convert biodegradable wastes into biochars [1,7-9]. Biochars can be produced from biodegradable waste of both plant origin, e.g., straw, wood chips, nutshell, sawdust and sewage sludge and poultry manure [10-14]. Biochar production is maximized during slow pyrolysis [15], with a slow rate of temperature increase $\left(0.01-2{ }^{\circ} \mathrm{C} \cdot \mathrm{s}^{-1}\right)$ [16]. Slow pyrolysis can enhance phosphorus availability, which is favorable for the use of biochars $[14,17,18]$ and is able to generate carbon abatement by the treatment of any type of waste [19]. Waste pyrolysis, especially high-temperature pyrolysis [20], can be an effective means of fixing metals in the process products, which can be of large importance for the treatment, among others, of sewage sludge often contaminated by heavy metals. The elements such as Fe, $\mathrm{Zn}, \mathrm{Mn}$ and $\mathrm{Cu}$ are volatilized at temperatures higher than $700-800{ }^{\circ} \mathrm{C}$ [10]. The concentration of mineral nutrients is higher in the biochar produced at higher temperatures $[10,21]$.

As demonstrated by multidirectional research, biochars can be used in a number of applications in environmental engineering or protection, among others, as an additive enhancing the "effectiveness of the composting" [22-28] (especially in the case of the treatment of substrates with substantial nitrogen content) or a material reducing greenhouse gas or odor emissions [11,29-31] which often occur during the composting process [32]. Biochars can be used as additives improving soil properties [33-35], reducing [36] the bioavailability of contaminants [37], enhancing plant growth and yield [33,34], and affecting the mobility of heavy metals [8,38-42] and their accumulation in plant biomass [43]. An extensively investigated application is the use of biochars as adsorbents of contaminants from different media [44-47].

The use and positive effect of biochars depend on its properties $[10,48]$ and, in turn, these primarily result from the type of substrate used for its production, the pyrolysis temperature [10,48-53] and the heating rate [7,54]. The type of gas used in the pyrolysis process may affect properties of the obtained products [55]. The feedstocks for biochar production are characterized by a different elemental composition and lignocellulose content that affect the capacity of biochars to adsorb organic contaminants [11]. Therefore, in order to obtain a product with the expected properties, the type of feedstock and the parameters of the pyrolysis process have to be appropriately combined $[8,36]$. The pyrolysis temperature determines a number of properties of biochars and, as a result, their uses [48]. It affects the specific surface area, porosity, sorption capacity, ion exchange properties, $\mathrm{pH}$, elemental composition, organic carbon content, presence of functional groups, stability of biochars and hydrophilicity of their surface $[3,8,15,16,45,47,50,56-62]$.

The sorption capacity of biochars has been investigated by many authors in relation to both inorganic and organic substances [11,52,63-66]. Biochars can be used for the sorption of contaminants, among others, from aqueous solutions $[47,65,67,68]$. The capacity of biochars to adsorb different components makes them potential nutrient carriers, which are very desirable and attractive for environmental applications [6,12,68-70]. A large specific surface area, porosity, ion exchange capacity and thermal stability of biochars affect their sorption properties [69]. In addition to the specific surface, the presence of non-carbonized organic matter, hydrophobicity and aromaticity of biochars also affect the sorption of specific components $[11,66]$. The properties of the biochars described above are determined by the pyrolysis temperature. A higher temperature of this process can improve the sorption capacity of biochars [71]. However, a high biochar production temperature is not always correlated with high adsorption capacity [68-70]. This means that biochars produced at both lower and higher temperatures can be good sorbents depending on particular biochar properties and binding mechanisms typical for different chemical substances. The metal sorption could be the results of mechanisms based, among others, on electrostatic interactions, ion exchange, binding of metals by functional groups present on the surface of biochars or precipitation $[58,72]$. These mechanisms are determined by the properties of biochars prevailing in products derived at lower or higher temperatures [44]. The presence 
of organic carbon phases, rich in surface functional groups, in biochar contributes to alkaline $\mathrm{pH}$, negative charge, cation exchange and the ability to form organometallic complexes. Mineral components can ensure metal sorption as a result of electrostatic attraction, ion exchange, surface complexation and precipitation of metal sediments by releasing soluble ions [72].

Thus, by controlling the pyrolysis temperature, biochar sorbents can be produced for different applications, and their attractiveness can be effectively enhanced by modifying chemical and physical processes or creating composites with other raw materials $[2,46,64,69,73-76]$. The use of sorbents from waste materials can be a more economical process, given the high costs of commercial sorbents [44].

As other authors have concluded [56], the research to determine the optimum conditions for biochar production from different raw materials continues to be necessary in order to identify a complete set of parameters that would enable biochar production for a specific application $[36,56]$. The research done to date $[7,8,11,52,77]$ confirms the need to appropriately design the properties of biochars to ensure that their use in the environment brings the expected benefits.

The production of biochar sorbents can compete with commercial products that are much more expensive. It can contribute to reducing the amount of landfilled or incinerated waste, as a result of the production of added-value products that can be included in the technological cycle, e.g., wastewater treatment plants, biogas plants, composting plants, or landfills. Therefore, the main goal of our work was the valorization of selected types of waste, in terms of practical use, among others in sorption processes. The aim of the research was to show the effect of pyrolysis temperature on the properties of the produced biochars and to present the characteristics of biochars produced from various wastes. The novelty of the conducted research was the analysis of the correlation of the influence of the type of precursor and the temperature of the pyrolysis process on the properties of the produced biochars. The results of this analysis may prove helpful in designing the valorization process of selected types of waste in the pyrolysis process. They can help assess the suitability of the produced biochars for various applications and choose the method of modifying their properties.

\section{Materials and Methods}

\subsection{Substrates for Biochar Production}

Biodegradable wastes of plant origin, i.e., walnut shell (WS), beech wood chips (WC) and wheat and rye straw (WRS) were used for biochar production. The moisture content $(\mathrm{MC})$, organic matter $(\mathrm{OM})$ in dry mass, ash, $\mathrm{pH}$, the Kjeldahl nitrogen content $\left(\mathrm{N}_{\mathrm{K}}\right)$ and the total carbon (TC) in dry mass-were determined for the particular substrates (Table 1). The highest total carbon content was found in beech wood chips and walnut shell, while a slightly lesser content of that component was determined for wheat and rye straw. Wheat and rye straw had the highest total nitrogen content at a level of about $0.5 \%$. The determined $\mathrm{pH}$ was diversified for the particular substrates. Straw was characterized by a neutral reaction, while beech wood chips and walnut shell had a slightly acidic reaction. The water content in the substrates fell within the range of 7.19 to $13.38 \%$.

Table 1. Selected properties of substrates for biochar production.

\begin{tabular}{lcccccc}
\hline & $\mathbf{M C} \%$ & $\mathbf{O M}_{\mathbf{d m}}$ & $\mathbf{A s h} \boldsymbol{~}_{\mathbf{d m}}$ & $\mathbf{p H}_{\mathbf{H} 2 \mathbf{O}}$ & $\mathbf{N}_{\mathbf{K}} \%$ & $\mathbf{T C} \%_{\mathbf{d m}}$ \\
\hline WRS & $11.96 \pm 1.52$ & $96.08 \pm 1.75$ & $3.91 \pm 1.75$ & 7.05 & 0.507 & 44.260 \\
\hline WS & $13.38 \pm 0.17$ & $98.94 \pm 0.10$ & $1.06 \pm 0.10$ & 4.98 & 0.299 & 49.923 \\
\hline WC & $7.19 \pm 0.04$ & $99.34 \pm 0.41$ & $0.66 \pm 0.41$ & 5.11 & 0.213 & 50.101 \\
\hline
\end{tabular}

\subsection{Parameters of the Pyrolysis Process}

The substrates were subjected to thermal conversion in a pyrolysis reactor (PRW-S100 $\times 780 / 11$ (Figure 1 ) in a nitrogen atmosphere $\left(5 \mathrm{~L} \cdot \mathrm{min}^{-1}\right)$. The pyrolysis reactor was man- 
ufactured by the Polish company Czylok (Jastrzębie-Zdrój, Poland) for the Czestochowa University of Technology. It is a tube furnace constructed on the basis of two-half heating and insulation modules. The heating temperatures of the substrate were: $400{ }^{\circ} \mathrm{C}, 500^{\circ} \mathrm{C}$, $600{ }^{\circ} \mathrm{C}$ and $700{ }^{\circ} \mathrm{C}$. The heating times of samples were $120 \mathrm{~min}$ for temperatures $400{ }^{\circ} \mathrm{C}$ and $500{ }^{\circ} \mathrm{C}$ and $150 \mathrm{~min}$ for temperatures of $600{ }^{\circ} \mathrm{C}$ and $700{ }^{\circ} \mathrm{C}$ respectively. The retention time was $60 \mathrm{~min}$. After the pyrolysis process was completed, the samples were left in the reactor until they reached room temperature. Biochar samples were stored in tightly closed containers in room temperature.

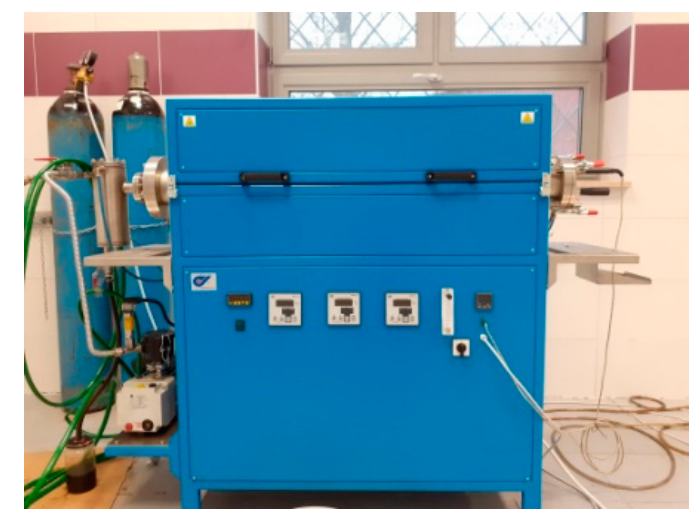

Figure 1. Pyrolysis reactor used for the production of biochar.

\subsection{Physicochemical and Physical Analyses}

The substrates and the obtained biochars were analyzed for moisture content (by oven drying at $105{ }^{\circ} \mathrm{C}$ ), organic matter (by incineration in a muffle furnace at $550{ }^{\circ} \mathrm{C}$ for $5 \mathrm{~h}$ and then calculate loss of weight based on certain assumptions) and ash (in accordance with PN-EN ISO 18122:2016-01 [78]). Substrates were analyzed for total carbon content (by Multi N/C, Analytkjena-the high-temperature incineration with detection IR [79]) and Kjeldahl nitrogen content (in accordance with PN-EN 16169:2012 [80]). pH measurement was made by placing $5 \mathrm{~g}$ of the sample in three, individual beakers and then adding distilled water to each of them $(50 \mathrm{~mL})$. The beakers were shaken for $10 \mathrm{~min}$ and then infiltrated. $\mathrm{pH}$ was measured by $\mathrm{pH}$ meter. Biochars derived at selected temperatures were analyzed for elemental composition, total organic carbon content, surface area, morphology and presence of surface functional groups. The CHNS elemental analysis was performed with the Thermo Scientific ${ }^{\mathrm{TM}}$ FLASH 2000 method of dynamic incineration (3-4 independent incineration). Total organic carbon content was indicated by analyzer TOC-5000A (made by Shimadzu, Kioto, Japan) with SSM 5000 attachment. TOC was indicated by high-temperature incineration $\left(900^{\circ} \mathrm{C}\right)$. Carbon dioxide was measured by infrared spectrometry and expressed as carbon. The BET surface area was indicated by the ASAP 2420. The ASAP 2420 analyzer (company Micromeritics, Norcross, GA, USA) measures single and multi-point specific surface areas and size and distribution of pore solid samples. The analytical techniques included scanning electron microscopy (SEM), which was used to examining the morphology of samples and chemical analysis (EDS). Surface functional groups were identified by Attenuated Total Reflectance Fourier transform infrared spectroscopy.

\subsection{Statistical Analysis}

The statistical analyses were conducted using IBM SPSS Statistics 26 . The significance level was $\alpha=0.05$. To investigate the relationship of the type of substrate and the pyrolysis temperature with the parameters of the obtained biochar, an experimental study was conducted in a $3 \times 4$ intergroup plan. Independent variables were biomass type (3) and pyrolysis temperature (4). The dependent variables were the six parameters of the obtained biochar- $\mathrm{pH}$, ash (ash content), N (nitrogen content), C (carbon content), $\mathrm{H}$ (hydrogen content) and BET (BET specific surface area). The results of this experiment were analyzed 
with a two-factor variance analysis for the intergroup plan in a $3 \times 4$ scheme. Post hoc testing was performed using the Bonferroni test.

\section{Results and Discussion}

\subsection{Pyrolysis Process Yield}

The implementation of the pyrolysis process in the temperature range of $400{ }^{\circ} \mathrm{C}$ to $700{ }^{\circ} \mathrm{C}$ produced a biochar yield in the range of 22.0 to $40.5 \%$. The process yield fell with increasing process temperature (Table 2), as other studies have also demonstrated [50,81-83]. This dependence results from the decomposition of organic compounds as the process temperature grows [10]. A higher process yield at a lower temperature is more desirable, given the reduced costs [48].

Table 2. Biochar production yields at different temperatures and properties of the biochars produced.

\begin{tabular}{|c|c|c|c|c|c|c|c|c|c|c|}
\hline \multirow{2}{*}{$\begin{array}{l}\text { Type of } \\
\text { Biochar }\end{array}$} & Yield & \multirow{2}{*}{$\mathrm{pH}_{\mathrm{H} 2 \mathrm{O}}$} & OM & Ash & $\mathbf{N}$ & $\mathrm{C}$ & $\mathbf{H}$ & $S$ & TOC & $\mathrm{H} / \mathrm{C}$ \\
\hline & $\%$ & & \multicolumn{7}{|c|}{ \% d.m. } & \\
\hline $\mathrm{BWRS}_{400}$ & 34.4 & $8.35 \pm 0.08$ & $89.45 \pm 0.45$ & $10.55 \pm 0.45$ & $0.28 \pm 0.07$ & $69.11 \pm 0.69$ & $3.87 \pm 0.04$ & - & 69.0 & 0.67 \\
\hline $\mathrm{BWRS}_{500}$ & 29.5 & $9.52 \pm 0.04$ & $88.36 \pm 0.50$ & $11,64 \pm 0.50$ & $0.32 \pm 0.05$ & $74.40 \pm 0.13$ & $2.97 \pm 0.01$ & - & 69.9 & 0.48 \\
\hline BWRS $_{600}$ & 29.1 & $9.89 \pm 0.01$ & $86.12 \pm 0.22$ & $13.88 \pm 0.22$ & $0.65 \pm 0.01$ & $77.32 \pm 0.12$ & $2.33 \pm 0.13$ & - & 76.5 & 0.36 \\
\hline BWRS $_{700}$ & 25.5 & $10.10 \pm 0.11$ & $85.56 \pm 0.61$ & $14.44 \pm 0.61$ & $0.98 \pm 0.12$ & $78.48 \pm 0.19$ & $1.45 \pm 0.12$ & - & 77.9 & 0.22 \\
\hline $\mathrm{BWS}_{400}$ & 40.5 & $5.98 \pm 0.06$ & $98.94 \pm 0.28$ & $1.06 \pm 0.28$ & - & $79.40 \pm 1.16$ & $3.96 \pm 0.06$ & - & 79.2 & 0.60 \\
\hline $\mathrm{BWS}_{500}$ & 34.2 & $6.90 \pm 0.05$ & $98.05 \pm 0.09$ & $1.95 \pm 0.09$ & - & $78.03 \pm 5.93$ & $3.22 \pm 0.03$ & - & 77.3 & 0.49 \\
\hline $\mathrm{BWS}_{600}$ & 31.4 & $7.37 \pm 0.01$ & $97.38 \pm 0.17$ & $2.62 \pm 0.17$ & - & $63.24 \pm 0.95$ & $2.20 \pm 0.02$ & - & 62.5 & 0.42 \\
\hline $\mathrm{BWS}_{700}$ & 30.2 & $9.85 \pm 0.01$ & $97.00 \pm 0.31$ & $3.00 \pm 0.31$ & - & $77.38 \pm 0.67$ & $1.38 \pm 0.05$ & - & 76.4 & 0.21 \\
\hline $\mathrm{BWC}_{400}$ & 31.7 & $4.45 \pm 0.04$ & $98.65 \pm 0.08$ & $1.35 \pm 0.08$ & - & $76.65 \pm 0.35$ & $4.20 \pm 0.11$ & - & 75.6 & 0.66 \\
\hline $\mathrm{BWC}_{500}$ & 25.1 & $5.18 \pm 0.03$ & $98.81 \pm 0.06$ & $1.18 \pm 0.06$ & - & $82.39 \pm 0.81$ & $3.02 \pm 0.01$ & - & 81.9 & 0.44 \\
\hline $\mathrm{BWC}_{600}$ & 23.2 & $6.57 \pm 0.04$ & $98.51 \pm 0.05$ & $1.49 \pm 0.05$ & - & $88.03 \pm 6.61$ & $2.53 \pm 0.32$ & - & 87.0 & 0.34 \\
\hline $\mathrm{BWC}_{700}$ & 22.0 & $7.82 \pm 0.03$ & $98.37 \pm 0.08$ & $1.61 \pm 0.08$ & - & $\begin{array}{c}84.61 \pm \\
10.03\end{array}$ & $1.47 \pm 0.14$ & - & 84.0 & 0.21 \\
\hline
\end{tabular}

The highest biochar yield from the substrates used in the study, reaching a level of $40.5 \%$, was determined for the lowest temperature applied $\left(400^{\circ} \mathrm{C}\right)$, while for a temperature of $700{ }^{\circ} \mathrm{C}$ it fell within the range of 22.0 to $30.2 \%$. Similar yield levels were found in other studies during the pyrolysis of plant substrates [51,60]. The authors of [60] found a decrease in the yields of solid pyrolysis products from $37.1 \%$ to less than $20 \%$ for a temperature increase in the range of $377-678^{\circ} \mathrm{C}$. The pyrolysis of pelletized sunflower husk produced the process yield of about 33.9-31.6\% at temperatures in the range of 480 to $580^{\circ} \mathrm{C}$ [51]. In the present study, the highest process yield among substrates was found for walnut shell, while the lowest one could be seen for beech wood chips. These results confirm the dependence of the pyrolysis process yields on the type of substrate subjected to conversion, as also demonstrated by $[45,50,84]$. This dependence is very conspicuous even within individual wood types. In their research, the authors of [48] found a significantly higher pyrolysis process yield for oak wood than the one in the research on beech wood considered above. The most effective process in the present study turned out to be the pyrolytic conversion of walnut shell carried out at a temperature of $400^{\circ} \mathrm{C}$. Other authors $[1,85]$ have come to similar conclusions, demonstrating that the pyrolysis temperature within the range of 350 to $400{ }^{\circ} \mathrm{C}$ is the optimum temperature enabling the yield at a level of $45-35 \%$ to be achieved in the biochar production from plant crop residues.

The yield of the pyrolysis of plant wastes carried out at a temperature of $400{ }^{\circ} \mathrm{C}$ was much lower than that in the case of the pyrolytic conversion of wastes of animal origin, e.g., poultry manure [50] or sewage sludge [12]. In their research, the authors of [50] achieved a 
$51.52 \%$ biochar yield of the pyrolysis of poultry manure at a temperature of $400{ }^{\circ} \mathrm{C}$, while the authors of [12] attained a $49 \%$ biochar yield. The differences in biochar yields from different wastes results from their different chemical characteristics related, among others, to ash content [50] or lignin content [86].

\subsection{Chemical Characteristics of the Biochar Produced}

The biochars produced in the pyrolysis of plant substrates, denoted as BWRS (biochar from wheat and rye straw), BWS (biochar from walnut shell) and BWC (biochar from beech wood chips) were subjected to a physico-chemical analysis, including the determination of the contents of organic matter $(\mathrm{OM})$, ash, nitrogen $(\mathrm{N})$, carbon $(\mathrm{C})$, hydrogen $(\mathrm{H})$, sulphur (S), total organic carbon (TOC in dry mass) and $\mathrm{pH}$. Table 2 shows the results of the analysis.

The biochars produced from wheat and rye straw were alkaline as their $\mathrm{pH}$ fell within the range of 8.31 to 10.13 , making them a potential agent to reduce soil acidity [48]. The biochars produced from walnut shell and beech wood chips were characterized by lower $\mathrm{pH}$ values, falling, respectively, within the ranges of 5.91 to 9.86 and 4.42 to 7.85 . The determined $\mathrm{pH}$ values of biochars produced from different plant substrates confirmed the tendency for $\mathrm{pH}$ values to grow with increasing temperature of the pyrolysis process and the differentiation of $\mathrm{pH}$ values depending on the type of substrate, as presented by other authors $[45,48,50]$. The changes in the $\mathrm{pH}$ of biochars accompanying temperature changes are caused by the production of organic acids and phenolic compounds from the decomposition of cellulose and hemicellulose at low temperatures, and the release of volatile substances (composed of acidic functional groups) [10] and increased ash content (the presence of alkaline mineral compounds) at higher temperatures [8].

As a result of the analyses of the dependent $\mathrm{pH}$ variable a statistically significant main effect of the type of substrate variable was achieved. The post hoc tests of the analyzed variable showed statistically significant differences in each variant of substrate comparisons. This means that the BWRS biochar has the highest $\mathrm{pH}$, followed by the BWS biochar, and the BWC biochar is characterized by the lowest $\mathrm{pH}$. The main effect of the pyrolysis temperature variable was also statistically significant. The post hoc tests also proved to be statistically significant in each variant of pyrolysis temperature comparisons with the $\mathrm{pH}$ variable. This result indicates a trend where a lower pyrolysis temperature is associated with a lower $\mathrm{pH}$ of the produced biochar, the lowest $\mathrm{pH}$ is achieved at $400{ }^{\circ} \mathrm{C}$ and the highest at $700{ }^{\circ} \mathrm{C}$.

A statistically significant effect of the interaction of the two factors on the $\mathrm{pH}$ level of the produced biochar was also achieved. Analysis of simple effects revealed significant statistical differences in all comparisons made in pairs, thus revealing a trend in which pyrolysis temperature is associated with $\mathrm{pH}$ levels in biochar groups. This result means that the increase in pyrolysis temperature is associated with a higher $\mathrm{pH}$ level among all three types of produced biochar. The results are presented in Tables 3 and 4 .

Table 3. The results of the two-factor analysis of variance testing the diversity of biochar properties in terms of the type of substrate and pyrolysis temperature.

\begin{tabular}{lcccccc}
\hline & $\mathbf{p H}$ & $\mathbf{A s h}$ & $\mathbf{N}$ & $\mathbf{C}$ & $\mathbf{H}$ & BET \\
\hline Main effect-type of substrate & $13,749.03^{* * *}$ & $5134.79^{* * *}$ & $681.22^{* * *}$ & 0.08 & $5.08^{*}$ & $12,447.77^{* * *}$ \\
\hline Main effect-temperature & $5486.10^{* * *}$ & $86.53^{* * *}$ & $58.53^{* * *}$ & 1.85 & $737.42^{* * *}$ & $8096.43^{* * *}$ \\
\hline Interactive effect-type of substrate ${ }^{*}$ temperature & $446.88^{* * *}$ & $24.27^{* * *}$ & $58.53^{* * *}$ & 2.16 & $3.56^{*}$ & $2807.52^{* * *}$ \\
\hline & ${ }^{*} p<0.05 ; * * * 0.001$. & & &
\end{tabular}


Table 4. The mean and standard deviation of biochar properties in relation to the type of substrate and pyrolysis temperature.

\begin{tabular}{|c|c|c|c|c|c|c|c|c|c|c|c|c|c|}
\hline & & \multicolumn{2}{|c|}{$\mathrm{pH}$} & \multicolumn{2}{|c|}{ Ash } & \multicolumn{2}{|c|}{$\mathbf{N}$} & \multicolumn{2}{|c|}{ C } & \multicolumn{2}{|c|}{$\mathbf{H}$} & \multicolumn{2}{|c|}{ BET } \\
\hline & & $\mathbf{M}$ & SD & $\mathbf{M}$ & SD & $\mathbf{M}$ & SD & $\mathbf{M}$ & SD & $\mathbf{M}$ & SD & $\mathbf{M}$ & SD \\
\hline \multicolumn{2}{|c|}{ BWRS } & 9.47 & 0.71 & 12.63 & 1.71 & 0.56 & 0.30 & 74.83 & 3.79 & 2.66 & 0.93 & 7.41 & 3.94 \\
\hline \multicolumn{2}{|c|}{ BWS } & 7.53 & 1.50 & 2.16 & 0.79 & 0.00 & 0.00 & 74.51 & 7.33 & 2.69 & 1.03 & 81.79 & 80.23 \\
\hline \multicolumn{2}{|c|}{ BWC } & 6.01 & 1.35 & 1.41 & 0.18 & 0.00 & 0.00 & 76.53 & 24.94 & 2.81 & 1.04 & 191.51 & 156.48 \\
\hline \multicolumn{2}{|c|}{400} & 6.26 & 1.70 & 4.32 & 4.68 & 0.09 & 0.14 & 66.54 & 25.38 & 4.01 & 0.16 & 2.70 & 1.45 \\
\hline \multicolumn{2}{|c|}{500} & 7.20 & 1.89 & 4.92 & 5.05 & 0.11 & 0.16 & 78.27 & 4.58 & 3.07 & 0.12 & 37.28 & 39.40 \\
\hline \multicolumn{2}{|c|}{600} & 7.94 & 1.50 & 6.00 & 5.93 & 0.22 & 0.33 & 76.20 & 11.27 & 2.35 & 0.23 & 161.65 & 131.26 \\
\hline \multicolumn{2}{|c|}{700} & 9.26 & 1.08 & 6.35 & 6.11 & 0.33 & 0.49 & 80.16 & 6.05 & 1.43 & 0.10 & 172.66 & 156.15 \\
\hline \multirow{4}{*}{ BWRS } & 400 & 8.35 & 0.08 & 10.55 & 0.45 & 0.28 & 0.07 & 69.11 & 0.69 & 3.87 & 0.04 & 4.52 & 0.06 \\
\hline & 500 & 9.52 & 0.04 & 11.64 & 0.50 & 0.32 & 0.05 & 74.40 & 0.13 & 2.97 & 0.01 & 12.99 & 0.07 \\
\hline & 600 & 9.89 & 0.01 & 13.88 & 0.22 & 0.65 & 0.01 & 77.32 & 0.12 & 2.33 & 0.13 & 8.71 & 0.05 \\
\hline & 700 & 10.10 & 0.11 & 14.44 & 0.61 & 0.98 & 0.12 & 78.48 & 0.19 & 1.45 & 0.12 & 3.43 & 0.06 \\
\hline \multirow{4}{*}{ BWS } & 400 & 5.98 & 0.06 & 1.06 & 0.28 & 0.00 & 0.00 & 79.40 & 1.16 & 3.96 & 0.06 & 1.23 & 0.02 \\
\hline & 500 & 6.90 & 0.05 & 1.95 & 0.09 & 0.00 & 0.00 & 78.03 & 5.93 & 3.22 & 0.03 & 9.11 & 0.13 \\
\hline & 600 & 7.37 & 0.01 & 2.62 & 0.17 & 0.00 & 0.00 & 63.24 & 0.95 & 2.20 & 0.02 & 164.48 & 1.83 \\
\hline & 700 & 9.85 & 0.01 & 3.00 & 0.31 & 0.00 & 0.00 & 77.38 & 0.67 & 1.38 & 0.05 & 152.35 & 4.00 \\
\hline \multirow{4}{*}{ BWC } & 400 & 4.45 & 0.04 & 1.35 & 0.08 & 0.00 & 0.00 & 51.10 & 44.26 & 4.20 & 0.11 & 2.36 & 0.05 \\
\hline & 500 & 5.18 & 0.03 & 1.18 & 0.06 & 0.00 & 0.00 & 82.39 & 0.81 & 3.02 & 0.01 & 89.73 & 2.86 \\
\hline & 600 & 6.57 & 0.04 & 1.49 & 0.05 & 0.00 & 0.00 & 88.03 & 6.61 & 2.53 & 0.32 & 311.77 & 4.04 \\
\hline & 700 & 7.82 & 0.03 & 1.61 & 0.08 & 0.00 & 0.00 & 84.61 & 10.03 & 1.47 & 0.14 & 362.19 & 7.44 \\
\hline
\end{tabular}

$\mathrm{M}-$ mean; SD—standard deviation.

The analysis of the ash content in the biochars showed the highest ash content in the BWRS biochars. This content fell within the range of $10.55 \%$ to $14.44 \%$. The remaining biochars had a lower ash content in the range of $1.06-3.00 \%$ (BWS) and 1.18-1.61\% (BWC). Biochar generated at higher pyrolysis temperature had higher ash content. This tendency was also observed by other researchers $[50,60]$. The ash content in biochars of plant origin is lower than in the case of biochars produced from fecal substrates [50,60].

Calculations involving ash dependent variable revealed the statistically significant main effect of the type of substrate variable. Comparisons in pairs, post hoc, of the analyzed variable showed statistically significant differences between all types of biomass. The difference in ash variable level between BWS and BWC biochar is very low and the confidence intervals in the post hoc test are approaching zero. Further analysis of contrasts did not show statistically significant differences in ash levels in the BWC biochar group. It can, therefore, be assumed that, despite the significant result of the a posteriori analysis, the a priori result prejudges the absence of differences between the BWS and BWC biochar groups. Thus, BWRS biochar has a higher ash content compared to BWS and BWC biochar, but there are no differences in the ash levels between BWS and BWC biochar. The main effect of pyrolysis temperature variable has also proved to be statistically significant. The post hoc tests were statistically significant in all comparison in pairs groups, except for the comparison of the $600{ }^{\circ} \mathrm{C}$ temperature with $700{ }^{\circ} \mathrm{C}$. This result reveals a trend in which higher temperatures are associated with more ash in the tested biochar, but there are no differences in ash levels during pyrolysis at $600{ }^{\circ} \mathrm{C}$ and $700{ }^{\circ} \mathrm{C}$.

Statistically significant was also the effect of the interaction of both factors on ash levels in produced biochar. A post hoc analysis of the simple effects for the BWRS biochar group showed statistically significant differences in ash levels between all pyrolysis temperature levels except the $600{ }^{\circ} \mathrm{C}$ with $700{ }^{\circ} \mathrm{C}$ comparison. In the BWS biochar group, differences 
in ash levels were statistically significant for all comparisons in pairs, except for $500{ }^{\circ} \mathrm{C}$ with $600{ }^{\circ} \mathrm{C}$ and $600{ }^{\circ} \mathrm{C}$ with $700{ }^{\circ} \mathrm{C}$. In the BWC biochar group, no statistically significant differences between pyrolysis temperature levels were revealed. This means that a higher temperature is associated with more ash in BWRS biochar, although this association fades above $600{ }^{\circ} \mathrm{C}$. Similarly, the BWS biochar has a higher amount of ash with a higher temperature, but it is not observed to differ at temperatures of $500^{\circ} \mathrm{C}$ and $600{ }^{\circ} \mathrm{C}$ as well as $600{ }^{\circ} \mathrm{C}$ and $700{ }^{\circ} \mathrm{C}$. The temperature is unrelated to the level of ash in BWC biochar. The details of the analyses carried out are set out in Tables 3 and 4 .

The organic carbon content in the biochars produced fell within the range of $62.5 \%$ to $87.0 \%$. Generally organic carbon content was found to grow with increasing temperature in the biochars produced from all the substrates. Taking into account the requirements of the European Biochar Certificate [87] for the organic carbon content in biochars applied in agriculture, all the biochars produced met the condition that the organic carbon content should be higher than $50 \%$ dry weight.

An elemental analysis to determine the carbon content in the biochars demonstrated that the content of this element increased as the temperature of the pyrolysis process increased. It was only in the case of the biochars produced from the walnut shell substrate that the carbon content did not clearly increase. The highest carbon content was determined in the case of the biochars produced from beech wood chips. In addition to the ion exchange capacity, this property helps plants take up nutrients [88], which is significant for the use of biochars for fertilizer production.

The analysis of the dependent variable $C$ did not show a statistically significant main effect of the type of substrate variable and the pyrolysis temperature variable. There was also no statistically significant effect of the interaction of the two factors on the amount of carbon in the produced biochar. It turns out that the biomass and pyrolysis temperature are not associated with the carbon content of the produced biochar. Tables 3 and 4 show the details of the carried-out analyses.

The hydrogen content in all the samples of the biochars analyzed decreased with an increasing temperature of the pyrolysis process, as a result of chemical reactions unfolding during the substrate pyrolysis process (dehydration, loss of $\mathrm{C}$-bound $\mathrm{H}$ atoms caused by thermal degradation) [21]).

The main effect of the substrate type variable on the dependent variable $\mathrm{H}$ was statistically significant. The post hoc analyses revealed only one statistically significant difference between BWRS and BWC biochar, differences in hydrogen content between BWRS and BWS and BWS and BWC groups are statistically insignificant. The main effect of the pyrolysis temperature variable was also statistically significant. The post hoc analysis calculations of the tested variable revealed statistically significant differences in each variant of pyrolysis temperature comparisons regarding hydrogen content in biochar. This result indicates a trend in which a lower pyrolysis temperature is associated with more hydrogen in the tested biochar.

A statistically significant effect of the interaction of the two factors on the hydrogen content of the produced biochar was achieved. The simple effect calculations revealed statistically significant differences in all comparisons made in pairs, thus showing a trend in which pyrolysis temperature is associated with hydrogen content in biochar groups. This means that a lower pyrolysis temperature is associated with a higher hydrogen content among all three types of produced biochar. The results of the analyses are presented in Tables 3 and 4 .

The value of the $\mathrm{H} / \mathrm{C}$ ratio decreased with an increasing pyrolysis temperature at which the biochars were produced. The decreasing $\mathrm{H} / \mathrm{C}$ ratio indicates carbonization and increased aromaticity of the products derived $[10,53]$. In accordance with the requirements of [87], the H/C ratio should not exceed 0.7 . This requirement was met by all the biochars produced. The aromaticity of biochars can indicate their stability and, accordingly, their greater carbon sequestration potential [88]. The composition affecting the stability of biochars [72]. 
An analysis of the nitrogen content in the biochars from walnut shell and beech wood chips did not demonstrate the presence of this element as a result of its low content in these substrates. The nitrogen content in the biochars from wheat and rye straw fell within the range of 0.28 to $0.98 \%$ and grew with an increasing process temperature, which might be caused by the presence of nitrogen compounds with a structure resilient to thermal degradation [10]. No sulfur was found in the biochars examined.

When analyzing the dependent variable $\mathrm{N}$, the statistically significant main effect of the type of substrate variable was revealed. Comparisons in pairs (post hoc analysis) showed two statistically significant differences between biomass of the BWRS and the BWS type, as well as between BWRS and BWC, differences in nitrogen content level between the BWS and BWC groups are statistically insignificant. The mean nitrogen content of BWS and BWC biochar is 0 , this result indicates that the BWRS biochar has a higher nitrogen content compared to zero amounts of this element in BWS and BWC biochar. The main effect of pyrolysis temperature variable has also proven to be statistically significant. The post hoc tests of the tested variable revealed statistically significant differences in each variant of pyrolysis temperature comparisons in terms of nitrogen content in biochar, except for differences between $400{ }^{\circ} \mathrm{C}$ and $500{ }^{\circ} \mathrm{C}$ biochar. This result means that higher temperatures are associated with more nitrogen in the tested biochar, but there are no noticeable differences between pyrolysis at $400{ }^{\circ} \mathrm{C}$ and pyrolysis at $500^{\circ} \mathrm{C}$.

The effect of interactions between the two factors on the nitrogen content of the produced biochar has turned out to be statistically significant. The analysis of simple effects revealed statistically significant differences only in the BWRS type biochar group, between all pairs of pyrolysis temperature variables, except for differences between biochar produced at $400{ }^{\circ} \mathrm{C}$ and $500{ }^{\circ} \mathrm{C}$. Other temperature differences in the BWS and BWC biomass groups were statistically insignificant, as their mean is 0 . It appears, therefore, that the increase in pyrolysis temperature is associated with a higher nitrogen content in the case of biochar of the BWRS type, while in other types of biochar it decreases to zero. The results are presented in Tables 3 and 4 .

\subsection{BET Specific Surface Area and Microstructure of Biochars}

The specific surface area (BET) of the biochars produced from plant origin substrates can range from 1 to $363 \mathrm{~m}^{2} \cdot \mathrm{g}^{-1}$ (Table 5). This diversity depends on the type and origin of a substrate which was used for production of biochar. The literature reports many studies on the effect of temperature on various properties of biochars, including the specific surface area $[3,50,57-59,89]$. For example, this was confirmed by the study on beech wood chips and walnut shell where the increase in temperature of pyrolysis led to the increase in specific surface area. Larger specific surface areas determined for products of plant origin derived at higher temperatures might be caused by the decomposition of lignocelullose and the evaporation of mineral inorganic substances [3,90]. Giudicianni et al. (2017) [60] achieved a wide specific surface range for biochars produced from plant biomass, which, however, had been earlier subject to the impact of steam. In this context, the authors of [60] emphasized a positive effect of steam which contributed to the desorption and removal of volatile substances, in contrast to the pyrolysis in a nitrogen atmosphere which generated products with lower porosity due to the deposition of carbonaceous material inside biochar pores. This phenomenon could also occur in the case of biochars analyzed in this study.

Table 5. BET specific surface area of biochar produced at different temperatures.

\begin{tabular}{lcccc}
\hline \multirow{2}{*}{ Type of Biochar } & $\mathbf{4 0 0}{ }^{\circ} \mathbf{C}$ & $\mathbf{5 0 0}{ }^{\circ} \mathbf{C}$ & $\mathbf{6 0 0}^{\circ} \mathbf{C}$ & $\mathbf{7 0 0}^{\circ} \mathbf{C}$ \\
\cline { 2 - 5 } & \multicolumn{5}{c}{$\mathbf{m}^{\mathbf{2} \cdot \mathbf{g}^{-\mathbf{1}}}$} \\
\hline BWRS & 4 & 12 & 8 & 3 \\
\hline BWS & 1 & 9 & 164 & 152 \\
\hline BWC & 2 & 89 & 311 & 363 \\
\hline
\end{tabular}


Among the plant substrates, beech wood chips proved to be the best material for the production of biochars with the most developed specific surface area. As a result of their production at temperatures of $600^{\circ} \mathrm{C}$ and $700^{\circ} \mathrm{C}$, they had a specific surface area of more than $300 \mathrm{~m}^{2} \cdot \mathrm{g}^{-1}$. As a result of the pyrolysis temperature shift from $500{ }^{\circ} \mathrm{C}$ to $600{ }^{\circ} \mathrm{C}$, the specific surface area grew by almost $250 \%$. In their research, Liu et al. (2010) [44] determined the specific surface area of the biochar produced from pine wood at a temperature of $700{ }^{\circ} \mathrm{C}$ at a much lower level of $29 \mathrm{~m}^{2} \cdot \mathrm{g}^{-1}$, which, as the authors explained, could have been an effect of the softening and melting of pine wood components. However, Efika et al. (2018) [7] determined the specific surface area of the biochars produced from pine sawdust pellets at a temperature of $800{ }^{\circ} \mathrm{C}$, with a heating rate of $5^{\circ} \mathrm{C} \mathrm{min}-1$, at quite a high level of $219 \mathrm{~m}^{2} \cdot \mathrm{g}^{-1}$. In the present study, the specific surface area of the biochars produced from beech wood chips at a temperature of $400{ }^{\circ} \mathrm{C}$, was $2 \mathrm{~m}^{2} \cdot \mathrm{g}^{-1}$, i.e., similar to the one determined by the authors of [47] for the biochar derived, among others, from oak wood at temperatures of 400 and $450{ }^{\circ} \mathrm{C}$. As reported by Srinivasan et al. (2015) [88], the biochar sorption capacity is proportional to the specific surface area and aromaticity, and biochars with a large specific surface area $\left(>400 \mathrm{~m}^{2} \cdot \mathrm{g}^{-1}\right)$ can be very effective adsorbents. Among the analyzed biochars, only the biochar produced from beech wood chips at a temperature of $700{ }^{\circ} \mathrm{C}$ had the specific surface area closest to the area cited above. The other biochars had a much smaller BET specific surface area.

An analysis of the BET specific surface area of the biochars produced from walnut shell demonstrated that at a temperature of $600{ }^{\circ} \mathrm{C}$ the specific surface area of the biochars was about $164 \mathrm{~m}^{2} \cdot \mathrm{g}^{-1}$, and it did not exceed this value when the temperature rose to $700{ }^{\circ} \mathrm{C}$. Perhaps in the case of this substrate, an even higher pyrolysis temperature needs to be applied to increase the specific surface area. Analyzing the effect of temperature on the specific surface area of biochars, Hung et al. (2017) [3] found a rapid increase in the BET specific surface area from $6 \mathrm{~m}^{2} \cdot \mathrm{g}^{-1}$ at a temperature of $700{ }^{\circ} \mathrm{C}$ to $102 \mathrm{~m}^{2} \cdot \mathrm{g}^{-1}$ when the pyrolysis process was carried out at a temperature of $800^{\circ} \mathrm{C}$. Ahmad et al. (2012) [45] determined a much larger specific surface area in the case of biochars produced from soybean stover and peanut shell at temperatures of 300 and $700{ }^{\circ} \mathrm{C}$. They found specific surface areas, respectively, in the range of 5 to $420 \mathrm{~m}^{2} \mathrm{~g}^{-1}$ (soybean stover), and from 3 to $448 \mathrm{~m}^{2} \mathrm{~g}^{-1}$ (peanut shell). In the case of the biochars produced from wheat and rye straw, the biochars produced at a temperature of temperature $500{ }^{\circ} \mathrm{C}$ had the largest specific surface area, i.e., about $12 \mathrm{~m}^{2} \cdot \mathrm{g}^{1}$. In this case, an increase in the biochar production process temperature did not cause the specific surface area to grow. At temperatures of $600{ }^{\circ} \mathrm{C}$ and $700{ }^{\circ} \mathrm{C}$, the BET specific surface area was found to diminish, respectively, to $8 \mathrm{~m}^{2} \cdot \mathrm{g}^{-1}$ and $3 \mathrm{~m}^{2} \cdot \mathrm{g}^{-1}$. The lack of correlation between the specific surface area of biochars with increasing temperature might be caused by the heterogeneity of the substrate which was a mixture of wheat and rye straw. The authors of [53] found a much larger BET specific surface area for biochars produced from maize straw at a temperature of $600{ }^{\circ} \mathrm{C}$, i.e., about $353 \mathrm{~m}^{2} \cdot \mathrm{g}^{-1}$ (with $17.36 \%$ ash content).

An analysis involving the BET dependent variable showed a statistically significant main effect of the type of substrate variable. Comparisons in pairs through post hoc analysis showed statistically significant differences between all types of the used biomass. This means that the BWRS biochar has a smaller BET specific surface area compared to BWS and BWC biochar, and the BWS biochar has a smaller BET specific surface area compared to the BWC biochar. The main effect of the pyrolysis temperature variable has also proved to be statistically significant. The post hoc tests revealed statistically significant differences in all groups of comparisons in pairs. This result reveals a trend in which a higher pyrolysis temperature is associated with a larger BET specific surface area of the tested biochar.

The effect of the interaction of the two independent variables on the level of the BET dependent variable of the produced biochar turned out to be statistically significant. The post hoc analysis of the simple effects for the BWRS biochar group also showed two statistically significant differences in the level of the BET variable in comparison of the pyrolysis temperature of $400{ }^{\circ} \mathrm{C}$ with $500{ }^{\circ} \mathrm{C}$ and $500{ }^{\circ} \mathrm{C}$ with $700{ }^{\circ} \mathrm{C}$. Other tests 
of differences were revealed to be statistically insignificant. In the BWS biochar groups, differences in the BET variable level were statistically significant for all comparisons in pairs. Likewise, in the BWC biochar group, statistically significant differences between all pyrolysis temperature levels have been revealed. This result indicates a trend in which a higher pyrolysis temperature is associated with a larger BET specific surface area for the BWS and BWC biochar types. This trend is also present for BWRS biochar to a lesser degree. For BWS biochar, this trend reverses at $600{ }^{\circ} \mathrm{C}$ and $700{ }^{\circ} \mathrm{C}$. The details of the carried-out analyses are shown in Tables 3 and 4.

Activated carbon has the specific surface area of up to $1000 \mathrm{~m}^{2} \cdot \mathrm{g}^{-1}$; therefore, it seems necessary to apply activation processes in order to attain the large specific surface area of biochars $[46,73]$.

Figure 2 shows the microstructure of the biochars produced. In the photos, voids and macropores can be seen. A characteristic system resembling a honeycomb, which can reflect the carbon skeleton of the capillary biological structure of the lignocellulosic feedstock, can also be seen [8]. In the case of biochars produced from beech wood chips and walnut shell, a difference can be seen between the microstructure of the biochars produced at a temperature of $400{ }^{\circ} \mathrm{C}$ (Figure 2a,c) and at a temperature of $700{ }^{\circ} \mathrm{C}$ (Figure 2b,d). The higher-temperature biochars are characterized by a better developed surface area with visible macropores.

Figure 2c shows the microstructure of the biochars produced from walnut shell at a temperature of $400{ }^{\circ} \mathrm{C}$. Numerous, irregularly distributed lighter spots can be seen in the photo. In addition to carbon and oxygen, the EDS analysis of these areas (Figure 3a) demonstrated the presence of such elements as: $\mathrm{Na}, \mathrm{Mg}$, $\mathrm{Al}, \mathrm{Si}, \mathrm{P}, \mathrm{S}, \mathrm{K}, \mathrm{Ca}$ and Fe. In several cases, among the elements analyzed, the presence of $\mathrm{N}, \mathrm{Cl}, \mathrm{Ir}, \mathrm{F}, \mathrm{Ti}, \mathrm{Ba}$ and $\mathrm{Pt}$ was also determined. Figure 2a shows the microstructure of $\mathrm{BWC}_{400}$. In addition to carbon and oxygen, the EDS analysis of these biochars (Figure $3 b$ ) also demonstrated the presence of: $\mathrm{Al}, \mathrm{K}$ and $\mathrm{Ca}$. In addition, $\mathrm{Mg}$ appeared in $\mathrm{BWC}_{500}$ biochars (Figure $3 \mathrm{c}$ ) as well as in $\mathrm{Si}$ in $\mathrm{BWC}_{600}$ i $\mathrm{BWC}_{700}$ biochars. Figure $2 \mathrm{e}, \mathrm{f}$ show the microstructure of the biochars produced from wheat and rye straw at temperatures, respectively, of $50{ }^{\circ} \mathrm{C}$ and $700{ }^{\circ} \mathrm{C}$. The microstructures of these biochars were very similar. BWRS ${ }_{500}$ biochars were characterized by the largest specific surface area of about $12 \mathrm{~m}^{2} \cdot \mathrm{g}^{-1}$, while the biochars derived at a temperature of $700{ }^{\circ} \mathrm{C}$ had the smallest surface area, which was still regarded as small, at about $3 \mathrm{~m}^{2} \cdot \mathrm{g}^{-1}$. The EDS analysis of the biochars produced from wheat and rye straw at a temperature of $600{ }^{\circ} \mathrm{C}$ (Figure 3d) demonstrated the presence of $\mathrm{C}, \mathrm{O}, \mathrm{Mg}, \mathrm{Al}, \mathrm{Si}, \mathrm{S}, \mathrm{K}, \mathrm{Ca}$ and $\mathrm{N}$ (with the presence of the latter confirmed by the elemental analysis).

\subsection{Functional Groups in Biochars}

The presence of specific types of surface functional groups in biochars can indicate the potential possibilities of their use, among others, in the processes of removing different contaminants from the environment, e.g., heavy metals from water or wastewater [13]. The intensity of surface functional groups was distinctly lower in the case of the biochars produced at a pyrolysis temperature of $700{ }^{\circ} \mathrm{C}$ than it was in the case of those derived at a temperature of $400{ }^{\circ} \mathrm{C}$.

The analysis of the FTIR spectra (Figure 4) of biochar produced from beech wood chips (BWC) demonstrated the presence of stretching vibrations of $\mathrm{O}-\mathrm{H}$ bonds (for wavelengths of $3328 \mathrm{~cm}^{-1}$ ), only in the case of biochar derived at a temperature of $400{ }^{\circ} \mathrm{C}$. A similar situation was found in the case of the bending vibrations of $\mathrm{O}-\mathrm{H}$ bonds, the presence of which was found for wavelengths of $1209 \mathrm{~cm}^{-1}$, only in the case of $\mathrm{BWC}_{400}$. The absence of stretching and bending vibrations of $\mathrm{O}-\mathrm{H}$ bonds (or their lesser intensity) in the remaining samples of biochar from beech wood chips was probably caused, among others, by dehydration of the material and the loss of volatile substances, since $\mathrm{OH}$ groups are unstable at higher temperatures. A signal corresponding to stretching vibrations of $\mathrm{C}-\mathrm{H}$ bonds (i.e., $\mathrm{CH}_{2}$ and $\mathrm{CH}_{3}$ ), present in aliphatic compounds [49], was observed in the case of biochar produced at any temperature $\left(400,500,600,700{ }^{\circ} \mathrm{C}\right)$ in the range of approximately 
$3032-2915 \mathrm{~cm}^{-1}$ of the FTIR spectrum (Figure 4). In the study reported in [48], aliphatic functional groups, which could transform into aromatic structures resulting in a greater presence of phenolic functional groups (ethers) (with vibrations for wavelengths of 1000 to $1250 \mathrm{~cm}^{-1}$ ), were not determined in biochar produced at temperatures of $600{ }^{\circ} \mathrm{C}$ and more. This can result in the decreased ability of biochar to adsorb nutrients, which stems from the presence of acidic functional groups [50]. In the case of samples of the tested biochar (BWC), the intensity of signals corresponding to the vibrations in question had a tendency to fall with increasing temperature, most likely due to the breaking of relatively weak $\mathrm{C}-\mathrm{H}$ bonds [10]. The strongest signal corresponding to those vibrations was observed in the case of biochar produced at a temperature of $400{ }^{\circ} \mathrm{C}$. The presence of $\mathrm{CH}$ groups in the analyzed FTIR spectra additionally confirmed the presence of bands in the range of $1470-1397 \mathrm{~cm}^{-1}$, and this signal was attributed to the bending modes of these groups [10]. Signals corresponding to the vibrations in the range of approximately $1430 \mathrm{~cm}^{-1}$ could be attributed to the bending vibrations of $\mathrm{C}=\mathrm{C}$ and/or saturated $\mathrm{C}-\mathrm{H}$ in lignin and carbohydrates [4]. An increase in the pyrolysis temperature activated the processes of the conversion of organic components (lignin, cellulose, and hemicellulose) and the release of volatile substances [10]. Therefore, the absence of signals in the range mentioned above might indicate the degradation of lignin, which diminished the availability of any carbon, as such a situation took place in the case of $\mathrm{BWC}_{700}$. The analysis of FTIR spectra (Figure 4) of $B W C$ biochar demonstrated the presence of bands of the stretching vibrations of $C=O$ bonds (in the range of approximately $1700 \mathrm{~cm}^{-1}$ ) in samples derived at temperatures of $400{ }^{\circ} \mathrm{C}, 500{ }^{\circ} \mathrm{C}$, and $600{ }^{\circ} \mathrm{C}$. The intensity of these signals fell with the increasing of the temperature. The occurrence of the vibrations of this type in the range of approximately $1700 \mathrm{~cm}^{-1}$ might indicate the presence of ketones, quinones, and/or carboxylic carbon [8]. In the analyzed FTIR spectra (Figure 4) of BWC biochar (from the entire temperature range), signals coming from the stretching vibrations of $\mathrm{C}=\mathrm{C}$ bonds in the range of approximately $1594-1540 \mathrm{~cm}^{-1}$ were observed. The intensity of these signals fell with an increasing pyrolysis temperature. A pyrolysis temperature of $600{ }^{\circ} \mathrm{C}$ or higher could cause the breaking of many double $\mathrm{C}=\mathrm{C}$ bonds, resulting in a decrease in the content of structures with $\mathrm{C}=\mathrm{C}$ bonds in the biochar [48]. The signals observed, corresponding to the wave number in the range of approximately $1576 \mathrm{~cm}^{-1}$, might be related to the vibrations of the $\mathrm{C}=\mathrm{C}$ grouping in an aromatic ring, coupled with the $\mathrm{C}=\mathrm{O}$ carbonyl group [91]; this could indicate the generation of products with their structure containing an organooxygen structural grouping coupled with double $\mathrm{C}=\mathrm{C}$ bonds in aromatic rings. In the case of FTIR spectra (Figure 4) of BWC biochar, produced at temperatures $500{ }^{\circ} \mathrm{C}, 600^{\circ} \mathrm{C}$, and $700^{\circ} \mathrm{C}$, bands attributed to the stretching modes of the $\mathrm{C}-\mathrm{O}$ bonds were observed (in the range of approximately 1231-1005 $\mathrm{cm}^{-1}$ ), where their presence might suggest the emergence of aromatic ethers through the integration of oxygen atoms into cyclical carbon structures [91]. On the other hand, the absorption bands in the range of approximately $1050-850 \mathrm{~cm}^{-1}$ could be attributed to the stretching modes of $\mathrm{C}-\mathrm{O}$ and the bending modes of $\mathrm{O}-\mathrm{H}$ in alcohols, phenols, ethers, and esters [91]. The signals observed in the spectra of $\mathrm{BWC}_{600}$ and $\mathrm{BWC}_{700}$ biochar were the most intense of all the signals present in the FTIR spectra of that biochar. When combined with the largest specific surface area of the biochar produced from beech wood chips as described earlier, this feature may indicate the greatest potential of that biochar for the sorption of different types of contaminants. The presence of oxygencontaining functional groups on the surface of biochar is very desirable, mostly in the context of the application of biochar to immobilize metals. These groups are of large importance for the formation of organometallic complexes immobilizing heavy metals in soil (Pb (II), Cu (II), Ni (II) and Cd (II)) [9,41,92]. The analysis of the FTIR spectra of BWC biochar demonstrated the presence of the bending vibrations of $=\mathrm{C}-\mathrm{H}$ bonds in the range of approximately $874-98 \mathrm{~cm}^{-1}$, which might indicate the presence of polycyclic aromatic structures [8].

In the case of the biochar produced from walnut shell (BWS), the analysis of FTIR spectra (Figure 5) demonstrated the presence of stretching vibrations of $\mathrm{O}-\mathrm{H}$ bonds in 
products obtained at temperatures of $400{ }^{\circ} \mathrm{C}$ and $500{ }^{\circ} \mathrm{C}$. These vibrations were observed for wavelengths of $3332 \mathrm{~cm}^{-1}$ and $3387 \mathrm{~cm}^{-1}$, respectively. A similar situation was found in the case of the bending vibrations of $\mathrm{O}-\mathrm{H}$ bonds, the presence of which was found for wavelengths of $1247 \mathrm{~cm}^{-1}$ and $1263 \mathrm{~cm}^{-1}$, respectively, in $\mathrm{BWS}_{400}$ and BWS 500 biochar. A group of bands attributed to the stretching modes of the $\mathrm{C}-\mathrm{H}$ groups was observed in the case of $\mathrm{BWS}_{400}, \mathrm{BWS}_{500}$, and $\mathrm{BWS}_{600}$ biochar in the range of approximately $3050-2915 \mathrm{~cm}^{-1}$ of the FTIR spectrum (Figure 5). The analysis of FTIR spectra of samples of BWS biochar has demonstrated the presence of stretching vibrations of $\mathrm{C}=\mathrm{O}$ bonds in the case of biochar produced at the temperatures of $400{ }^{\circ} \mathrm{C}$ and $500^{\circ} \mathrm{C}$. This might be caused, among others, by the presence of juglone-a substance present in walnut shell which is an organic chemical compound from the group of quinone dyes. In all the analyzed FTIR spectra (Figure 5) of the studied BWS biochar, signals coming from the stretching vibrations of $\mathrm{C}=\mathrm{C}$ bonds (in the range of approximately $1594-1540 \mathrm{~cm}^{-1}$ ) were observed, the intensity of which was decreasing with the increase of the pyrolysis temperature. Bands assigned to stretching modes of $\mathrm{C}-\mathrm{O}$ bonds were observed in the FTIR spectra of BWS biochar samples (in the range of approximately $1231-1005 \mathrm{~cm}^{-1}$ ). These vibrations were determined in all the biochar produced from walnut shell, except for $\mathrm{BWS}_{500}$, but this have been caused by the hampered analysis of its spectrum. The analysis of the FTIR spectra of BWS biochar (Figure 5) demonstrated the presence of the bending vibrations of $=\mathrm{C}-\mathrm{H}$ bonds in the range of approximately $874-98 \mathrm{~cm}^{-1}$.

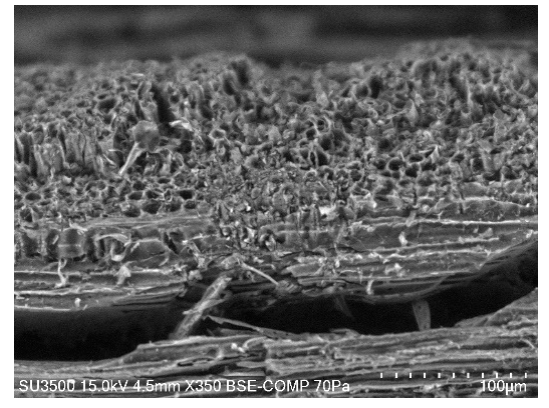

(a)

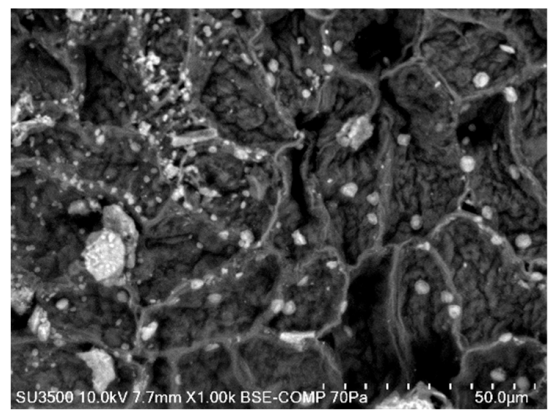

(c)

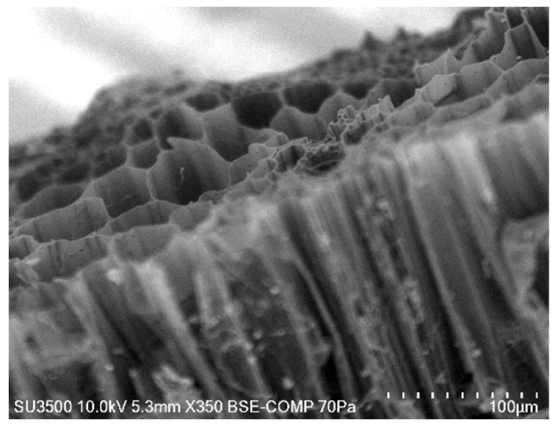

(e)

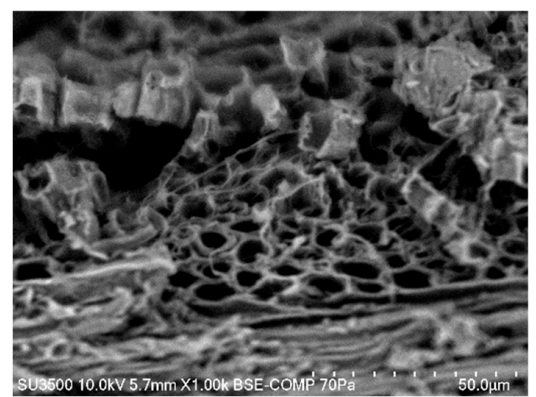

(b)

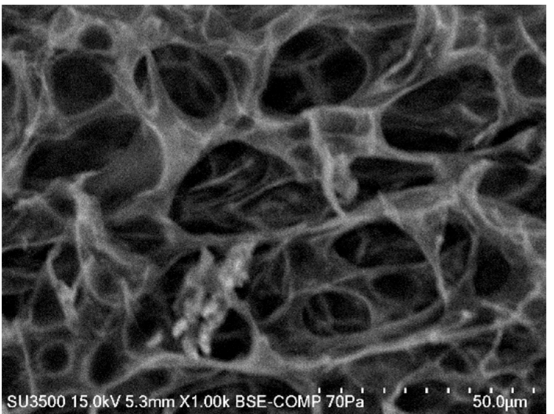

(d)

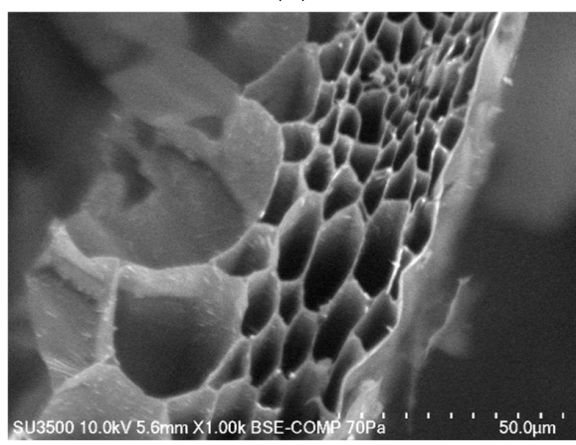

(f)

Figure 2. Microstructure of biochars: (a) $\mathrm{BWC}_{400} ;(\mathbf{b}) \mathrm{BWC}_{700} ;(\mathbf{c}) \mathrm{BWS}_{400} ;(\mathbf{d}) \mathrm{BWS}_{700} ;(\mathbf{e}) \mathrm{BWRS}_{500} ;(\mathbf{f}) \mathrm{BWRS}_{700}$. 


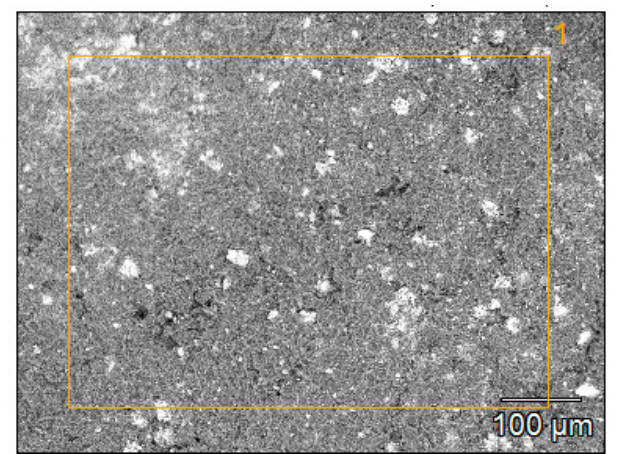

(a)

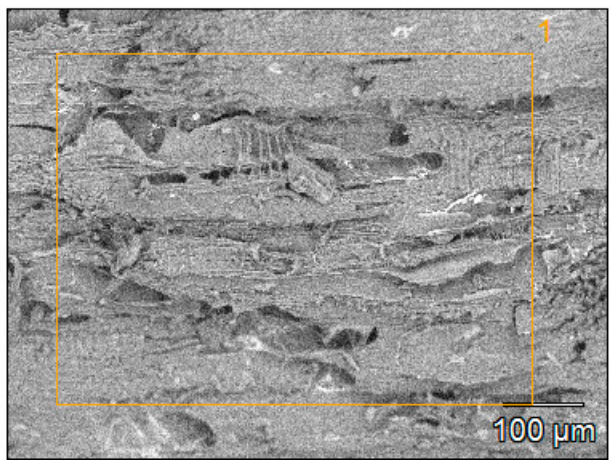

(c)

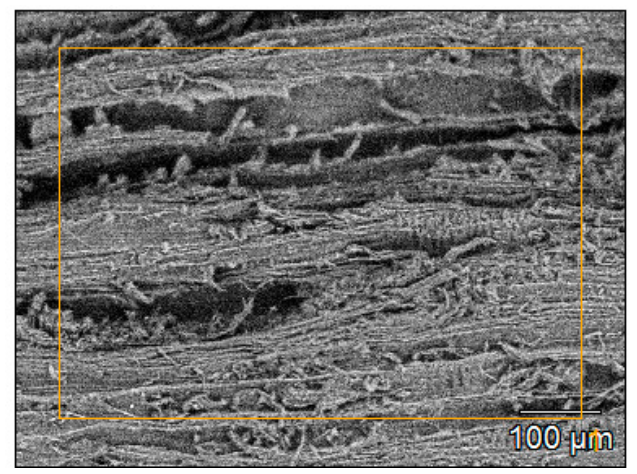

(b)

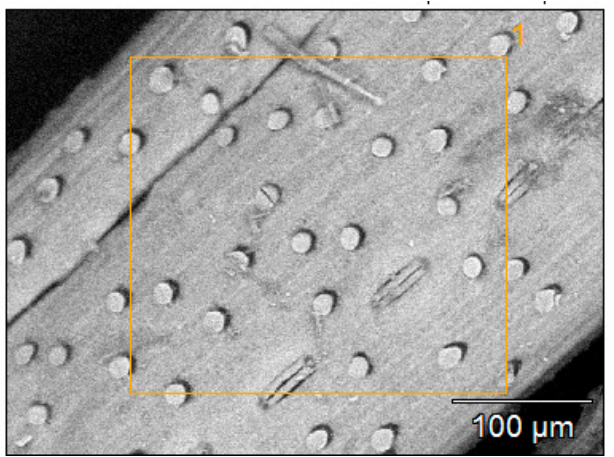

(d)

Figure 3. Surfaces of samples, with marked areas for which the elemental analysis was performed: (a) $\mathrm{BWS}_{600}$; $(\mathbf{b}) \mathrm{BWC}_{400}$; (c) $\mathrm{BWC}_{500} ;$ (d) $\mathrm{BWRS}_{600}$.

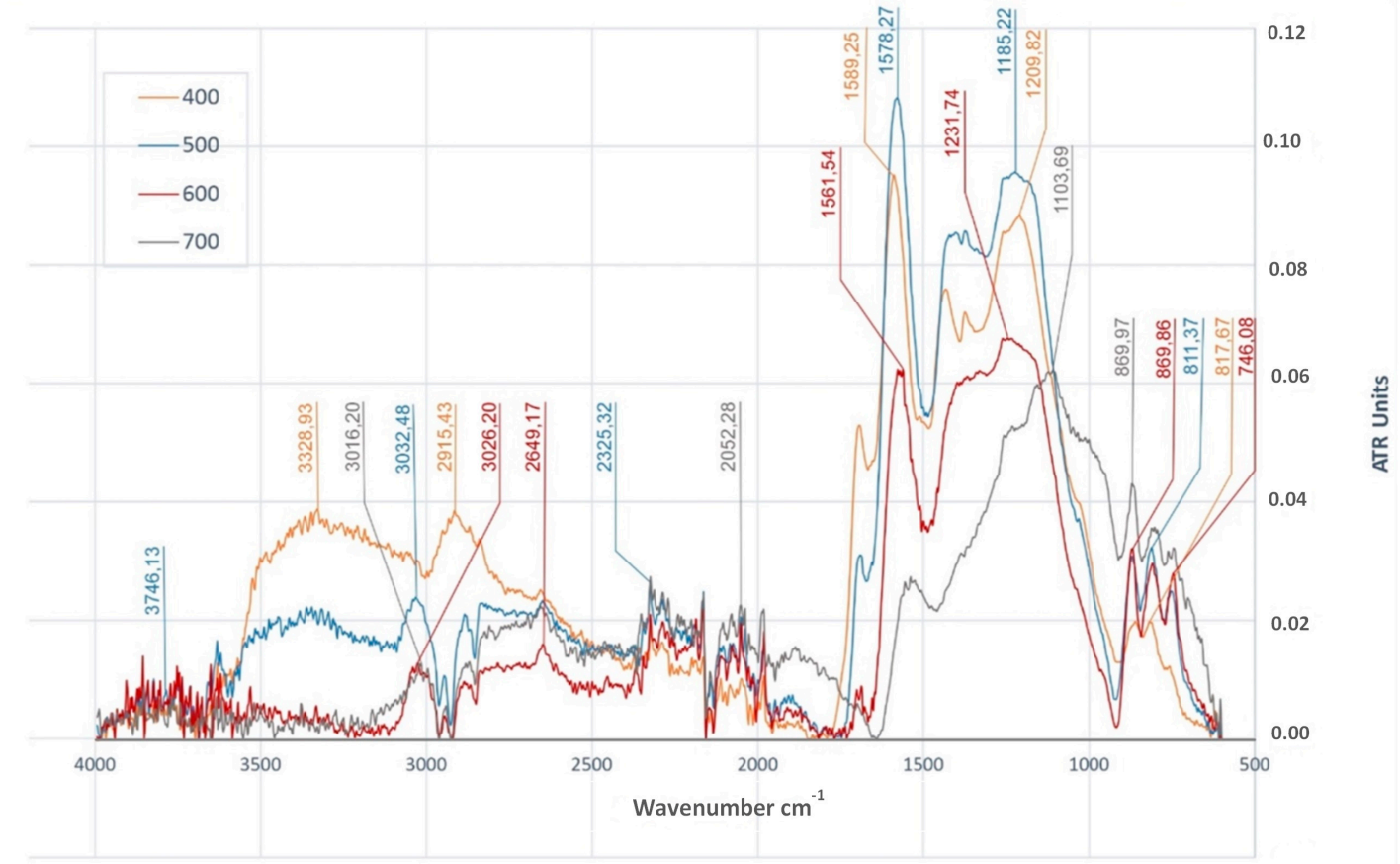

Figure 4. FTIR/ATR spectra of biochars produced at different temperatures $\left(400{ }^{\circ} \mathrm{C}, 500{ }^{\circ} \mathrm{C}, 600{ }^{\circ} \mathrm{C}\right.$ and $\left.700{ }^{\circ} \mathrm{C}\right)$ from beech wood chips. 


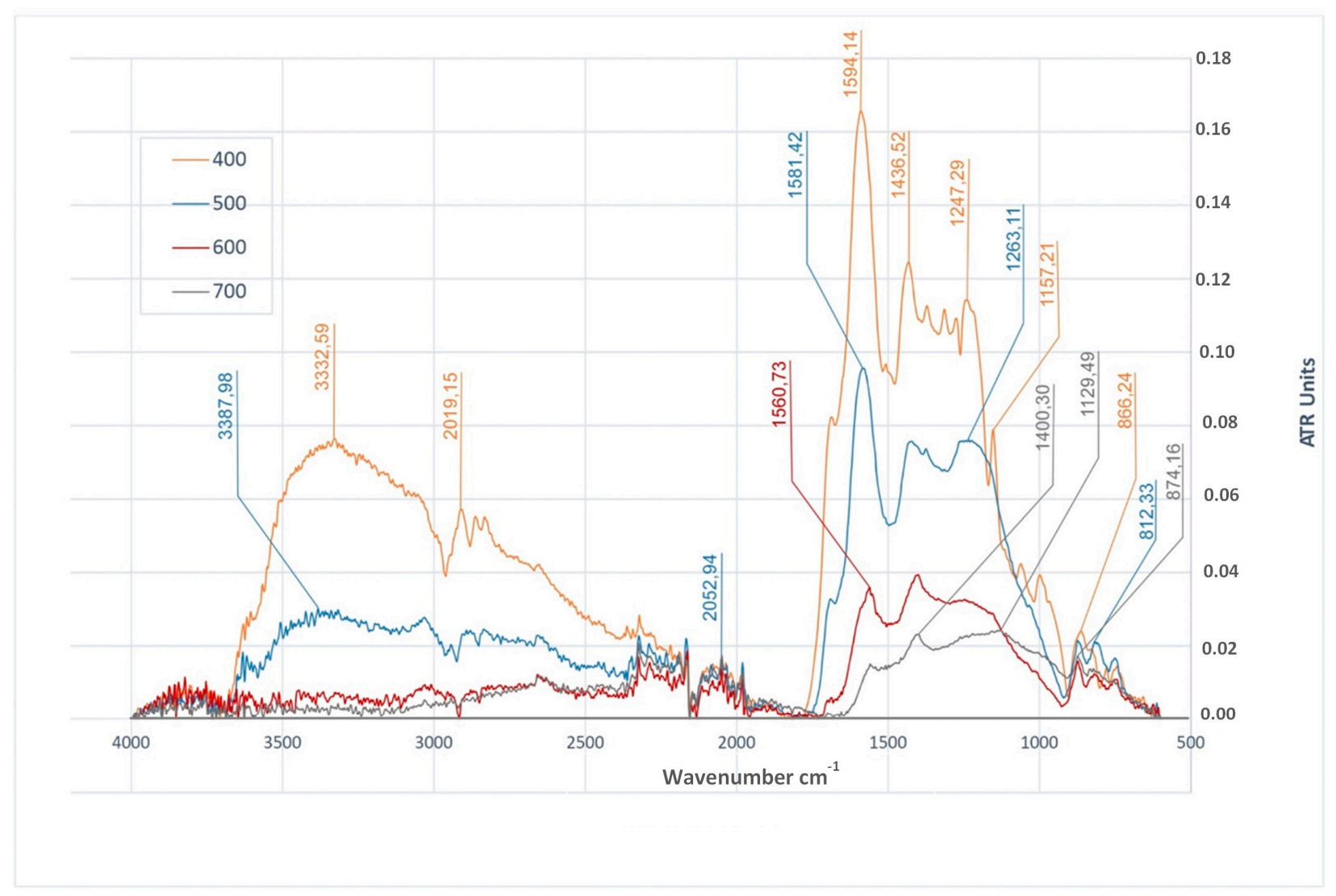

Figure 5. FTIR/ATR spectra of biochars produced at different temperatures $\left(400{ }^{\circ} \mathrm{C}, 500{ }^{\circ} \mathrm{C}, 600{ }^{\circ} \mathrm{C}\right.$ and $\left.700{ }^{\circ} \mathrm{C}\right)$ from walnut shell.

The analysis of FTIR spectra of biochar produced from wheat and rye straw (Figure 6) demonstrated the presence of stretching vibrations of $\mathrm{O}-\mathrm{H}$ bonds in the biochar derived at temperatures of $400{ }^{\circ} \mathrm{C}$ and $500{ }^{\circ} \mathrm{C}$, respectively for wavelengths of $3344 \mathrm{~cm}^{-1}$ and $3330 \mathrm{~cm}^{-1}$. In these samples, the presence of bending vibrations of $\mathrm{O}-\mathrm{H}$ bonds was also observed for wavelengths of $1220 \mathrm{~cm}^{-1}$ and about $1200 \mathrm{~cm}^{-1}$ in BWRS 400 and BWRS 500 biochar. A group of bands assigned to stretching modes of $\mathrm{C}-\mathrm{H}$ groups in the case of BWRS $_{400}$, BWRS $_{500,}$ and BWRS 600 biochar were observed in the range of approximately $3045-2922 \mathrm{~cm}^{-1}$ of the FTIR spectrum. The analysis of FTIR spectra (Figure 6) has also demonstrated the presence of bands of the stretching vibrations of $\mathrm{C}=\mathrm{O}$ bonds (in the range of approximately $1700 \mathrm{~cm}^{-1}$ ) in samples derived at temperatures of $400{ }^{\circ} \mathrm{C}, 500{ }^{\circ} \mathrm{C}$, and $600^{\circ} \mathrm{C}$. The intensity of these signals fell with the increasing temperature. In the analyzed FTIR spectra of all BWRS biochar, signals coming from stretching vibrations of $\mathrm{C}=\mathrm{C}$ bonds in the range of approximately $1594-1540 \mathrm{~cm}^{-1}$ were observed. The intensity of these signals also fell with the increasing pyrolysis temperature. Bands assigned to stretching modes of $\mathrm{C}-\mathrm{O}$ bonds were observed in the FTIR spectra of BWRS biochar samples in the range of approximately $1231-1005 \mathrm{~cm}^{-1}$. The bands corresponding to these vibrations were determined in the samples of all the biochar from wheat and rye straw and in the case of the biochar produced at temperatures of $600{ }^{\circ} \mathrm{C}$ and $700{ }^{\circ} \mathrm{C}$. These signals were the most intense of all the signals present in the spectra of the biochar produced at a given temperature. In the case of biochar with small specific surface area, this property can be compensated for by the presence of $\mathrm{C}-\mathrm{O}$ groups and have a positive effect on its sorption properties [88]. In the case of BWRS biochar, the analysis of the FTIR spectra has also demonstrated the presence of bending vibrations of $=\mathrm{C}-\mathrm{H}$ bonds in the range of approximately $874-98 \mathrm{~cm}^{-1}$ indicating the presence of polycyclic aromatic structures. 
It has been shown, inter alia, the influence of the type of precursor used in the production of biochar on the presence of surface functional groups. The presence of intense stretching vibrations of $\mathrm{C}-\mathrm{O}$ bonds, having a potential impact on the sorption capacity of biochars, was determined in the FTIR spectra of BWC600 and BWC700 biochars, this feature, combined with the large BET surface area, may affect the sorption potential of these biochars. The presence of this type of high-intensity vibrations was also observed in the spectra of biochar BWRS600 and BWRS700. This can compensate for the low BET surface value and play an important role when using these biochars in sorption processes for organic and inorganic compounds.

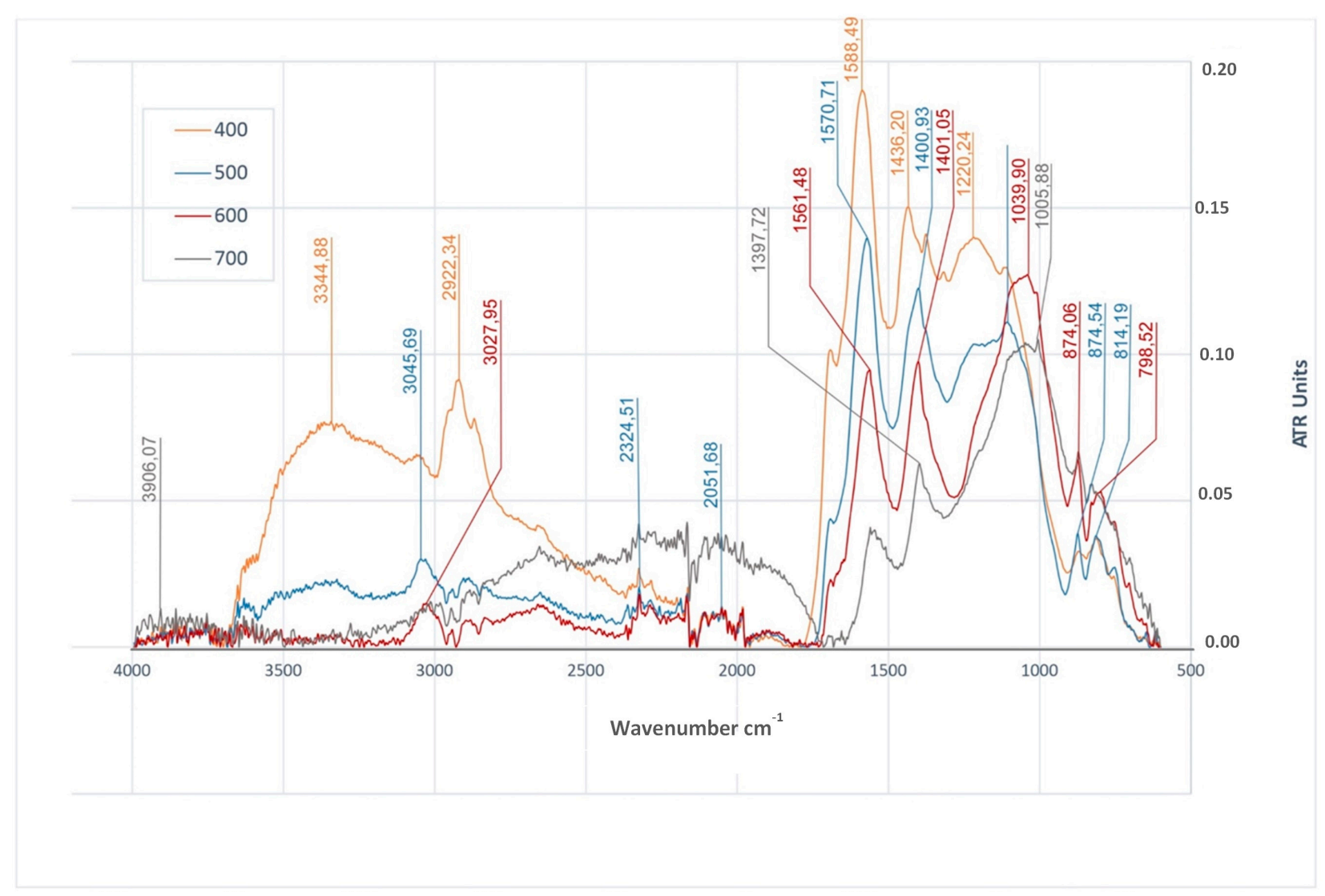

Figure 6. FTIR/ATR spectra of biochars produced at different temperatures $\left(400{ }^{\circ} \mathrm{C}, 500{ }^{\circ} \mathrm{C}, 600^{\circ} \mathrm{C}\right.$ and $\left.700{ }^{\circ} \mathrm{C}\right)$ from wheat and rye straw.

Table 6 collects data on spectral characteristics, their assignment to the functional groups of the biochar surface.

Table 6. FTIR Peak assignment of characteristic vibrations observed for biochars produced at different temperatures.

\begin{tabular}{|c|c|c|c|c|c|c|c|c|c|c|c|c|c|c|}
\hline \multirow{2}{*}{$\begin{array}{l}\text { FTIR Peak } \\
\mathrm{cm}^{-1}\end{array}$} & \multirow{2}{*}{$\begin{array}{l}\text { Characteristic } \\
\text { Vibrations }\end{array}$} & \multicolumn{4}{|c|}{ BWC } & \multicolumn{4}{|c|}{ BWS } & \multicolumn{4}{|c|}{ BWRS } & \multirow[b]{2}{*}{ References } \\
\hline & & $\begin{array}{l}400 \\
{ }^{\circ} \mathrm{C}\end{array}$ & $\begin{array}{l}500 \\
{ }^{\circ} \mathrm{C}\end{array}$ & $\begin{array}{l}600 \\
{ }^{6} \mathrm{C}\end{array}$ & $\begin{array}{l}700 \\
{ }^{\circ} \mathrm{C}\end{array}$ & $\begin{array}{l}400 \\
{ }^{\circ} \mathrm{C}\end{array}$ & $\begin{array}{l}{ }^{500} \\
{ }^{\circ} \mathrm{C}\end{array}$ & $\begin{array}{l}600 \\
{ }^{\circ} \mathrm{C}\end{array}$ & $\begin{array}{l}700 \\
{ }^{\circ} \mathrm{C}\end{array}$ & $\begin{array}{l}400 \\
{ }^{\circ} \mathrm{C}\end{array}$ & $\begin{array}{l}500 \\
{ }^{5} \mathrm{C}\end{array}$ & $\begin{array}{l}600 \\
{ }^{\circ} \mathrm{C}\end{array}$ & $\begin{array}{l}700 \\
{ }^{\circ} \mathrm{C}\end{array}$ & \\
\hline 3328-3387 & $\begin{array}{c}\mathrm{O}-\mathrm{H} \\
\text { stretching }\end{array}$ & + & - & - & - & + & + & - & - & + & + & - & - & {$[8,33,36,48,71,88]$} \\
\hline 2915-3050 & $\begin{array}{c}\mathrm{C}-\mathrm{H} \\
\text { stretching }\end{array}$ & + & + & + & + & + & + & + & - & + & + & + & - & {$[8,33,48,49,88,93]$} \\
\hline 1700 & $\begin{array}{c}\mathrm{C}=\mathrm{O} \\
\text { stretching }\end{array}$ & + & + & + & - & + & + & - & - & + & + & + & - & {$[8,36,52,71,88]$} \\
\hline 1540-1594 & $\begin{array}{c}\mathrm{C}=\mathrm{C} \\
\text { stretching }\end{array}$ & + & + & + & + & + & + & + & + & + & + & + & + & {$[8,33,36,48,71,88,91,93]$} \\
\hline $1397-1470$ & $\begin{array}{c}\mathrm{C}-\mathrm{H} \\
\text { deformation }\end{array}$ & + & + & + & - & + & + & + & + & + & + & + & + & {$[10,36,71]$} \\
\hline
\end{tabular}


Table 6. Cont.

\begin{tabular}{|c|c|c|c|c|c|c|c|c|c|c|c|c|c|c|}
\hline $1200-1290$ & $\begin{array}{c}\mathrm{O}-\mathrm{H} \\
\text { deformation }\end{array}$ & + & - & - & - & + & + & - & - & + & + & - & - & {$[8,93]$} \\
\hline 1005-1231 & $\begin{array}{c}\mathrm{C}-\mathrm{O} \\
\text { stretching }\end{array}$ & - & + & + & + & + & - & + & + & + & + & + & + & {$[8,33,52,88,91]$} \\
\hline $746-874$ & $\begin{array}{c}=\mathrm{C}-\mathrm{H} \\
\text { bending }\end{array}$ & + & + & + & + & + & + & + & + & + & + & + & - & {$[8,36,48,52,88]$} \\
\hline
\end{tabular}

${ }^{+}$observed; ${ }^{-}$not observed.

\section{Conclusions}

The pyrolytic conversion (in the temperature range of $400^{\circ} \mathrm{C}-700^{\circ} \mathrm{C}$ ) of biodegradable wastes of plant origin may produce biochars with diversified properties. The present study found a clear effect of pyrolysis process temperatures on the yield and selected properties of biochars. The biochar production yield was found to diminish with increasing temperature. In terms of the biochar production yield, walnut shell proved to be the most attractive substrate. Temperature changes affected the chemical composition of the products derived. With increasing temperature, the content of carbon in biochars also increased but hydrogen content decreased. This resulted in lower $\mathrm{H} / \mathrm{C}$ ratio. Increased $\mathrm{pH}$ and TOC values were also determined. Another parameter which demonstrated a growing tendency with increasing temperature was the BET specific surface area (except for BWRS). An increase in the pyrolysis temperature also caused a decrease in the diversity and intensity of the surface functional groups of biochars.

The alkaline character of biochars produced at higher temperatures makes them desirable materials to reduce soil acidity. High TOC content also confirms the potential for the use of biochars in agriculture. The increased carbonization and aromaticity of biochars produced at higher temperatures may determine their stability and carbon sequestration potential. The presence of oxygen-containing functional groups (the ability to form complexes) creates the potential opportunities for using such biochars as materials immobilizing selected heavy metals. The well-developed BET surface area and the presence of specific functional groups on the surface of biochars from beech wood chips may determine their adsorption capacity. Biochars produced at higher temperatures, poorer in carboxyl and hydroxyl groups, may show lesser capacity to adsorb $\mathrm{N}-\mathrm{NH}_{4}$.

The small specific surface area can be compensated for by the presence of specific functional groups and have a positive effect on their sorption properties. Therefore, the use of the biochars produced in the process of sorption of specific components, e.g., heavy metals or ammonia nitrogen, requires further research and possible modification of their properties in physical or chemical processes.

It is planned to continue the research aimed at checking the effectiveness of the use of the tested biochars in the sorption of ammonium nitrogen and phosphorus from the leachate produced during the treatment of sewage sludge or municipal waste, and to reduce ammonia emissions from gases emitted during composting.

Author Contributions: Conceptualization, K.W.; methodology, K.W.; software, K.W. and A.K.-K., validation, K.W. and A.K.-K.; formal analysis, K.W.; investigation, K.W.; resources, K.W.; data curation, K.W.; writing-original draft preparation, K.W.; writing-review and editing, A.K.-K.; visualization, K.W. and A.K.-K.; supervision, A.K.-K.; project administration, K.W.; funding acquisition, A.K.-K. All authors have read and agreed to the published version of the manuscript.

Funding: The scientific research was funded by the statute subvention of Czestochowa University of Technology, Faculty of Infrastructure and Environment. The research was funded by the project No. BS/PB400/301/21.

Institutional Review Board Statement: Not applicable.

Informed Consent Statement: Not applicable.

Data Availability Statement: Not applicable. 
Conflicts of Interest: The author declares no conflict of interest. The funders had no role in the design of the study; in the collection, analyses, or interpretation of data; in the writing of the manuscript, or in the decision to publish the results.

\section{References}

1. Dunnigan, L.; Morton, B.J.; Ashman, P.J.; Zhang, X.; Kwong, C.W. Emission characteristics of a pyrolysis-combustion system for the co-production of biochar and bioenergy from agricultural wastes. Waste Manag. 2018, 77, 59-66. [CrossRef] [PubMed]

2. Jin, J.W.; Wang, M.Y.; Cao, Y.C.; Wu, S.C.; Liang, P.; Li, Y.N.; Zhang, J.Y.; Zhang, J.; Wong, M.H.; Shan, S.D.; et al. Cumulative effects of bamboo sawdust addition on pyrolysis of sewage sludge: Biochar properties and environmental risk from metals. Bioresour. Technol. 2017, 228, 218-226. [CrossRef] [PubMed]

3. Hung, C.-Y.; Tsai, W.-T.; Chen, J.-W.; Lin, Y.-Q.; Chang, Y.-M. Characterization of biochar prepared from biogas digestate. Waste Manag. 2017, 66, 53-60. [CrossRef]

4. Taherymoosavi, S.; Verheyen, V.; Munroe, P.; Joseph, S.; Reynolds, A. Characterization of organic compounds in biochar derived from municipal solid waste. Waste Manag. 2017, 67, 131-142. [CrossRef]

5. Mohammadi, A.; Cowie, A.L.; Mai, T.L.A.; Brandão, M.; de la Rosa, R.A.; Kristiansen, P.; Joseph, S. Climate-change and health effects of using rice husk for biochar-compost: Comparing three pyrolysis systems. J. Clean. Prod. 2017, 162, 260-272. [CrossRef]

6. Barber, S.T.; Yin, J.; Draper, K.; Trabold, T.A. Closing nutrient cycles with biochar- from filtration to fertilizer. J. Clean. Prod. 2018, 197, 1597-1606. [CrossRef]

7. Efika, C.E.; Onwudili, J.A.; Williams, P.T. Infuence of heating rates on the products of high-temperature pyrolysis of waste wood pellets and biomass model compounds. Waste Manag. 2018, 76, 497-506. [CrossRef]

8. Zhao, B.; O'Connor, D.; Zhang, J.; Peng, T.; Shen, Z.; Tsang, D.C.W.; Hou, D. Effect of pyrolysis temperature, heating rate, and residence time on rapeseed stem derived biochar. J. Clean. Prod. 2018, 174, 977-987. [CrossRef]

9. Zhao, B.; Xu, H.; Zhang, T.; Nan, X.; Ma, F. Effect of pyrolysis temperature on sulfur content, extractable fraction and release of sulfate in corn straw biochar. RSC Adv. 2018, 8, 35611-35617. [CrossRef]

10. Bavariani, M.Z.; Ronaghi, A.; Ghasemi, R. Influence of pyrolysis tempeartures on FTIR analysis, nutrient bioavailability, and agricultural use of poultry manure biochars. Commun. Soil Sci. Plant Anal. 2019, 50, 402-411. [CrossRef]

11. Ahmed, M.J.; Hameed, B.H. Adsorption behavior of salicylic acid on biochar as derived from the thermal pyrolysis of barley straws. J. Clean. Prod. 2018, 195, 1162-1169. [CrossRef]

12. Bai, X.; Li, Z.; Zhang, Y.; Ni, J.; Wang, X.; Zhou, X. Recovery of ammonium in urine by biochar derived from faecal sludge and its application as soil conditioner. Waste Biomass Valorization 2018, 9, 1619-1628. [CrossRef]

13. Batool, S.; Idrees, M.; Hussain, Q.; Kong, J. Adsorption of copper (II) by using derived-farmyard and poultry manure biochars: Efficiency and mechanism. Chem. Phys. Lett. 2017, 689, 160-198. [CrossRef]

14. Kleemann, R.; Chenoweth, J.; Clift, R.; Morse, S.; Pearce, P. Comparison of phosphorus recovery from incinerated sewage sludge ash (ISSA) and pyrolysed sewage sludge char (PSSC). Waste Manag. 2017, 60, 201-210. [CrossRef]

15. Malińska, K.; Dach, J. Biochar as a supplementary material for biogas production. Ecol. Eng. 2015, 41, 117-124. (In Polish) [CrossRef]

16. Malińska, K. Biochar is a response to current environmental problems. Eng. Prot. Environ. 2012, 15, 387-403. (In Polish)

17. Roberst, D.A.; Cole, A.J.; Whelan, A.; de Nys, R.; Paul, N.A. Slow pyrolysis enhances the recovery and reuse of phosphorus and reduces metal leaching from biosolids. Waste Manag. 2017, 64, 133-139.

18. Li, F.; Liang, X.; Niyungeko, C.; Sun, T.; Liu, F.; Arai, Y. Effects of biochar amendments on soil phosphorus transformation in agricultural soils. Adv. Agron. 2019, 158, 131-172. [CrossRef]

19. Ibarrola, R.; Shackley, S.; Hammond, J. Pyrolysis biochar systems for recovering biodegradable materials: A life cycle carbon assessment. Waste Manag. 2012, 32, 859-868. [CrossRef]

20. Xu, X.; Zhao, B.; Sun, M.; Chen, X.; Zhang, M.; Li, H.; Shaucong, X. Co-pyrolysis characteristics of municipal sewage sludge and hazelnut shell by TG-DTG-MS and residue analysis. Waste Manag. 2017, 62, 91-100. [CrossRef]

21. Novak, J.M.; Lima, I.; Xing, B.; Gaskin, J.W.; Steiner, C.; Das, K.C.; Ahmedna, M.; Rehrah, D.; Watts, D.W.; Busscher, W.J.; et al. Charcterization of designer biochar produced at different temperatures and their effects on a loamy sand. Ann. Environ. Sci. 2009, 3, 195-206.

22. Mia, S.; Uddin, M.E.; Kader, M.A.; Ahsan, A.; Mannan, M.A.; Hossain, M.M.; Solaiman, Z.M. Pyrolysis and co-composting of municipal organic waste in Bangladesh: A quantitative estimate of recyclable nutrients, greenhouse gas emissions, and economic benefits. Waste Manag. 2018, 75, 503-513. [CrossRef] [PubMed]

23. Wang, Q.; Awasthi, M.K.; Ren, X.; Zhao, J.; Li, R.; Wang, Z.; Wang, M.; Chen, H.; Zhang, Z. Combing biochar, zeolite and wood vinegar for composting of pig manure: The effect on greenhouse gas emission and nitrogen conservation. Waste Manag. 2018, 74, 221-230. [CrossRef] [PubMed]

24. Sanchez-Monedero, M.A.; Cayuela, M.L.; Roig, A.; Jindo, K.; Mondini, C.; Bolan, N. Role of biochar as an additive in organic waste composting. Bioresour. Technol. 2018, 247, 1155-1164. [CrossRef] [PubMed]

25. Xiao, R.; Awasthi, M.K.; Li, R.; Park, J.; Pensky, S.M.; Wang, Q.; Wang, J.J.; Zhang, Z. Recent development in biochor utilization as an additive in organic solid waste composting: A review. Bioresour. Technol. 2017, 246, 203-213. [CrossRef] [PubMed] 
26. Godlewska, P.; Schmidt, H.P.; Ok, Y.S.; Oleszczuk, P. Biochar for composting improvement and contaminants reduction. A review. Bioresour. Technol. 2017, 246, 193-202. [CrossRef]

27. Agyarko-Mintah, E.; Cowie, A.; Singh, B.P.; Joseph, S.; Van Zwieten, L.; Cowie, A.; Harden, S.; Smillie, R. Biochar increases nitrogen retention and lowers greenhouse gas emissions when added to composting poultry litter. Waste Manag. 2017, 61, 138-149. [CrossRef]

28. Wang, X.; Zhao, Y.; Wang, H.; Zhao, X.; Cui, H.; Wei, Z. Reducing nitrogen loss and phytotoxicity during beer vinasse composting with biochar addition. Waste Manag. 2017, 61, 150-156. [CrossRef]

29. Maurer, D.L.; Koziel, J.A.; Kalus, K.; Andersen, D.S.; Opalinski, S. Pilot-scale testing of non-activated biochar for swine manure treatment and mitigation of ammonia, hydrogen sulfide, odorous volatile organic compounds $\left(\mathrm{VOC}_{\mathrm{s}}\right)$, and greenhouse gas emissions. Sustainability 2017, 9, 929. [CrossRef]

30. Janczak, D.; Malińska, K.; Czekała, W.; Caceres, R.; Lewicki, A.; Dach, J. Biochar to reduce ammonia emissions in gaseous and liquid phase during composting of poultry manure with wheat straw. Waste Manag. 2017, 66, 36-45. [CrossRef]

31. Malińska, K.; Zabochnicka-Świątek, M.; Dach, J. Effects of biochar amendment on ammonia emission during composting of sewage sludge. Ecol. Eng. 2014, 71, 474-478. [CrossRef]

32. Gutiérrez, M.C.; Siles, J.A.; Diz, J.; Chica, A.F.; Martin, M.A. Modeling of composting process of different organic waste at pilot scale: Biodegradability and odor emissions. Waste Manag. 2017, 59, 48-58. [CrossRef]

33. Ferreira, S.D.; Manera, C.; Silvestre, W.P.; Pauletti, G.F.; Altafini, C.R.; Godinho, M. Use of biochar produced from elephant grass by pyrolysis in a screw reactor as a soil amendment. Waste Biomass Valorization 2019, 10, 3089-3100. [CrossRef]

34. Czekała, W.; Jeżowska, A.; Chełkowski, D. The use of biochar for the production of organic fertilizers. J. Ecol. Eng. 2019, 20, 1-8. [CrossRef]

35. Agegnehu, G.; Srivastava, A.K.; Bird, M.I. The role of biochar and biochar-compost in improving soil quality and crop performance: A review. Appl. Soil Ecol. 2017, 119, 156-170. [CrossRef]

36. Zhang, H.; Chen, C.; Gray, E.M.; Boyd, S.E. Effect of feedstock and pyrolysis temperature on properties of biochor governing end use efficacy. Biomass Bioenergy 2017, 105, 136-146. [CrossRef]

37. Oleszczuk, P.; Rycaj, M.; Lehmann, J.; Cornelissen, G. Influence of activated carbon and biochar on phytotoxicity of air- dried sewage sludge to Lepidium sativum. Ecotoxicol. Environ. Saf. 2012, 80, 321-326. [CrossRef] [PubMed]

38. Zhou, H.; Meng, H.; Zhao, L.; Shen, Y.; Hou, Y.; Cheng, H.; Song, L. Effect of biochar and humic acid on the copper, lead, and cadmium passivation during composting. Bioresour. Technol. 2018, 258, 279-286. [CrossRef]

39. Liu, W.; Huo, R.; Xu, J.; Liang, S.; Li, J.; Zhao, T.; Wang, S. Effects of biochar on nitrogen transformation and heavy metals in sludge composting. Bioresour. Technol. 2017, 235, 43-49. [CrossRef]

40. Zama, E.F.; Zhu, Y.-G.; Reid, B.J.; Sun, G.-X. The role of biochar properties in influencing the sorption and desorption of Pb (II), $\mathrm{Cd}$ (II) and as (III) in aqueous solution. J. Clean. Prod. 2017, 148, 127-136. [CrossRef]

41. Xue, Y.; Gao, B.; Yao, Y.; Inyang, M.; Zhang, M.; Zimmerman, A.R.; Ro, K.S. Hydrogen peroxide modification enhances the ability of biochar (hydrochar) produced from hydrothermal carbonization of peanut hull to remove aqueous heavy metals: Batch and column tests. Chem. Eng. J. 2012, 200, 673-680. [CrossRef]

42. Uchimiya, M.; Chang, S.; Klasson, K.T. Screening biochars for heavy metal retention in soil: Role of oxygen functional groups. J. Hazard. Mater. 2011, 190, 432-441. [CrossRef]

43. Zhao, B.; Xu, R.; Ma, F.; Li, Y.; Wang, L. Effects of biochar derived from chicken manure and rape straw on speciation and phytoavailability of $\mathrm{Cd}$ to maize in artificially contaminated loess soil. J. Environ. Manag. 2016, 184, 569-574. [CrossRef]

44. Liu, Z.; Zhang, F.-S.; Wu, J. Characterization and application of chars produced from pinewood pyrolysis and hydrothermal treatment. Fuel 2010, 89, 510-514. [CrossRef]

45. Ahmad, M.; Lee, S.S.; Dou, X.; Mohan, D.; Sung, J.-K.; Yang, J.E. Effects of pyrolysis temperature on soybean stover-and peanut shell-derived biochar properties and TCE adsorption in water. Bioresour. Technol. 2012, 118, 536-544. [CrossRef]

46. Franciski, M.A.; Peres, E.C.; Godinho, M.; Perondi, D.; Foletto, E.L.; Collazzo, G.C.; Dotto, G.L. Development of $\mathrm{CO}_{2}$ activetd biochar from solid waste of a beer industry and its application for methylene blue adsorption. Waste Manag. 2018, 78, 630-638. [CrossRef]

47. Mohan, D.; Rajput, S.; Singh, V.K.; Steele, P.H.; Pitman, C.U., Jr. Modeling and evaluation of chromium remediation from using low cost bio-char, a green adsorbent. J. Hazard. Mater. 2011, 188, 319-333. [CrossRef]

48. Li, S.; Chen, G. Thermogravimetric, thermochemical, and infrared spectral characterization of feedstocks and biochar derived at different pyrolysis temperatures. Waste Manag. 2018, 78, 198-207. [CrossRef]

49. Vaughn, S.F.; Dinelli, F.D.; Kenar, J.A.; Jackson, M.A.; Thomas, A.J.; Peterson, S.C. Physical and chemical properties of pyrolyzed biosolids for utilization in sand-based turfgrass rootzones. Waste Manag. 2018, 76, 98-105. [CrossRef]

50. Song, W.; Guo, M. Quality variations of poultry litter biochar generated at different pyrolysis temperatures. J. Anal. Appl. pyrolysis 2012, 9, 138-145. [CrossRef]

51. Wystalska, K.; Malińska, K.; Włodarczyk, R.; Chajczyk, O. Effects of pyrolysis parameters on the yield and properties of biochar from pelletized sunflower husk. In E3S Web of Conferences; EDP Sciences: Les Ulis, France, 2018; Volume 44, p. 00197. [CrossRef]

52. De Bhowmick, G.; Sarmah, A.K.; Sen, R. Production and characterization of a value added biochar mix using seaweed, rice husk and pine sawdust: A parametric study. J. Clean. Prod. 2018, 200, 641-656. [CrossRef]

53. Li, J.; Cao, L.; Yuan, Y.; Wang, R.; Wen, Y.; Man, J. Comparative study for microcystin-LR sorption onto biochars produced from various plant- and animal- wastes at different pyrolysis temperatures: Influencing mechanisms of biochar properties. Bioresour. Technol. 2018, 24, 794-803. [CrossRef] 
54. Trubetskaya, A.; Jensen, P.A.; Jensen, A.D.; Steibel, M.; Spliethoff, H.; Glarborg, P. Influence of fast pyrolysis conditions on yield and structural transformation of biomass chars. Fuel Process. Technol. 2015, 140, 205-214. [CrossRef]

55. Konczak, M.; Oleszczuk, P. Co-pyrolysis of sewage sludge and biomass in carbon dioxide as a carrier gas affects the total and leachable metals in biochars. J. Hazard. Mater. 2020, 400, 123144. [CrossRef] [PubMed]

56. Manyà, J.J.; Azuara, M.; Manso, J.A. Biochar production through slow pyrolysis of different biomass materials: Seeking the best operating conditions. Biomass Bioenergy 2018, 117, 115-123. [CrossRef]

57. Sharma, R.K.; Wooten, J.B.; Baliga, V.L.; Martoglio-Smith, P.A.; Hajaligol, M.R. Characterization of char from the pyrolysis of tobacco. J. Agirc. Food Chem. 2002, 50, 771-783. [CrossRef] [PubMed]

58. Li, H.; Dong, X.; da Silva, E.B.; de Oliveira, L.M.; Chen, Y.; Ma, L.Q. Mechanism of metal sorption by biochars: Biochar characteristics and modifications. Chemosphere 2017, 178, 466-478. [CrossRef] [PubMed]

59. Hasnan, F.I.; Iamail, K.N.; Mus, M.; Jaapar, J.; Alwi, H.; Hamid, K.K. Characterization of bio char derived from tapioca skin. IOP Conf. Ser. Mater. Sci. Eng. 2018, 334, 012016. [CrossRef]

60. Giudicianni, P.; Pindozzi, S.; Grottola, C.M.; Stanzione, F.; Faugno, S.; Fagnano, M.; Fiorentino, N.; Ragucci, R. Pyrolysis for exploitation of biomasses selected for soil phytoremediation: Characterization of gaseous and solid products. Waste Manag. 2017, 61, 288-299. [CrossRef]

61. Shoi, S.; Lopez-Capel, E.; Krull, E.; Bol, R. Biochar climate and soil, A review to guide future research. CSIRO Land Water Sci. Rep. 2009, 5, 1-59.

62. Lehman, J. Bio-energy in the black. Front. Ecol Environ. 2007, 5, 381-387. [CrossRef]

63. Dai, Y.; Zhang, N.; Chuanming, X.; Cui, Q.; Sun, Q. The adsorption, regeneration and engineering application of biochar for removal organic pollutants. Chemosphere 2019, 223, 12-27. [CrossRef]

64. El-Banna, M.F.; Mosa, A.; Gao, B.; Yin, X.; Ahmad, Z.; Wang, H. Sorption of lead ions onto oxidized bagasse-biochar mitigates $\mathrm{Pb}$-induced oxidative stress on hydroponically grown chicory: Experimental observations and mechanisms. Chemosphere 2018, 208, 887-898. [CrossRef] [PubMed]

65. Regkouzas, P.; Diamadopoulos, E. Adsorption of selected organic micro-pollutants on sewage sludge biochar. Chemosphere 2019, 224, 840-851. [CrossRef]

66. Zhang, X.; Gao, B.; Zheng, Y.; Hu, X.; Creamer, A.E.; Annable, M.D.; Li, Y. Biochar for volatile organic compound (VOC) removal: Sorption performance and governing mechanisms. Bioresour. Technol. 2017, 245, 606-614. [CrossRef]

67. Yao, S.; Li, X.; Cheng, H.; Zhang, C.; Bian, Y.; Jiang, X.; Song, Y. Resource utylization of a typical vegetable waste as biochars in removing phthalate acid esters from water: A sorption case study. Bioresour. Technol. 2019, 293, 122081. [CrossRef]

68. Tang, Y.; Alam, M.A.; Konhauser, K.O.; Alessi, D.S.; Xu, S.; Tian, W.J.; Liu, Y. Influence of pyrolysis temperature on production of digested sludge biochar and its application for ammonium removal from municipal wastewater. J. Clean. Prod. 2019, 209, 927-936. [CrossRef]

69. Jiang, Y.-H.; Li, A.-Y.; Deng, H.; Ye, C.-H.; Wu, Y.-Q.; Linmu, Y.-D.; Hang, H.-L. Characteristics of nitrogen and phosphorus adsorption by Mg-loaded biochar from different feedstocks. Bioresour. Technol. 2019, 276, 183-189. [CrossRef]

70. Xu, D.; Cao, J.; Li, Y.; Howard, A.; Kewei, Y. Effect of pyrolysis temperature on characteristics of biochars derived from different feedstocks: A case study on ammonium adsorption capacity. Waste Manag. 2019, 87, 652-660. [CrossRef]

71. Fan, S.; Tang, J.; Wang, Y.; Li, H.; Zhang, H.; Tang, J.; Wang, Z.; Li, X. Biochar prepared from co-pyrolisis of municipal sewage sludge and tea waste for the adsorption of methylene blue from aqueous solution: Kinetics, isotherm, thermodynamic and mechanism. J. Mol. Liq. 2016, 220, 432-441. [CrossRef]

72. Qi, F.; Yan, Y.; Lamb, D.; Naidu, R.; Bolan, N.S.; Liu, Y.; Ok, Y.S.; Donne, S.W.; Semple, K.T. Thermal stability of biochar and its effects on cadmium sorption capacity. Bioresour. Technol. 2017, 246, 48-56. [CrossRef] [PubMed]

73. Mandal, S.; Sarkar, B.; Igalavithana, A.D.; Ok, Y.S.; Yang, X.; Lombi, E.; Bolan, N. Mechanistic insights of 2,4-D sorption onto biochar: Influence of feedstock material and biochar properties. Bioresour. Technol. 2017, 246, 160-167. [CrossRef] [PubMed]

74. Viglasova, E.; Galambos, M.; Dankova, Z.; Krivosudsky, L.; Lengauer, C.L.; Hood-Nowotny, R.; Soja, G.; Rompel, A.; Matik, M.; Briancin, J. Production, characterization and adsorption studies of bamboo-based biochar/montmorillonite composite for nitrate removal. Waste Manag. 2018, 79, 385-394. [CrossRef] [PubMed]

75. Xu, G.; Yang, X.; Spinosa, L. Development of sludge-based adsorbents: Preparation, characterization, utilization and its feasibility assessment. J. Environ. Manag. 2015, 151, 221-232. [CrossRef]

76. Devi, P.; Saroha, A.K. Utilization of sludge based adsorbents for the removal of various pollutants: A review. Sci. Total Environ. 2017, 578, 16-33. [CrossRef]

77. Rittl, T.F.; Butterbach-Bahl, K.; Basile, C.M.; Pereira, L.A.; Alms, V.; Dannenmann, M.; Couto, E.G.; Ceri, C.E.P. Greenhouse gas emissions from soil amended with agricultural residua biochars: Effects of feedstock type, production temperature and soil moisture. Biomass Bioenergy 2017, 117, 1-9. [CrossRef]

78. PN-EN ISO 18122:2016-01-Polish Version, Solid Biofuels-Determination of Ash Content.

79. PN-ISO 10694:2002—Soil Quality—Determination of Organic Carbon Content and Total Carbon Content after Dry Combustion (Elemental Analysis).

80. PN-EN 16169:2012—Polish Standard. Sewage Sludge, Treated Bio-Waste and Soil. Determination of Nitrogen by the Kjeldahl Method. 
81. Ahmad, M.; Rajapaksha, A.U.; Lim, J.E.; Zhang, M.; Bolan, D.M.; Vithanage, M.; Lee, S.S.; Ok, S.Y. Biochar as a sorbent for contaminant management In soil and water: A review. Chemosphere 2014, 99, 19-33. [CrossRef] [PubMed]

82. Brown, R. Biochar production technology. In Biochar for Environmental Management Science and Technology: Earth Scans; Lehmann, J., Joseph, S., Eds.; Earthscan Publ.: London, UK, 2009; pp. 127-146.

83. De Wildt, P.; Reith, H.; Heeres, H.J. Biomass pyrolysis for chemicals. Biofuels 2011, 2, 185-208. [CrossRef]

84. Yang, S.I.; Wu, M.S.; Wu, C.Y. Application of biomass fast pyrolysis part I: Pyrolysis characteristics and products. Energy 2014, 66, 162-171. [CrossRef]

85. Llorach-Massana, P.; Lopez-Capel, E.; Pena, J.; Rieradevall, J.; Montero, J.I.; Puy, N. Technical feasibility and carbon footprint of biochar co-production with tomato plant residue. Waste Manag. 2017, 67, 121-130. [CrossRef]

86. Ruiz-Gomez, N.; Quispe, V.; Abrego, J.; Atienza-Martinez, M.; Murillo, M.B.; Gea, G. Co-pyrolysis of sewage sludge and manure. Waste Manag. 2017, 59, 211-221. [CrossRef]

87. EBC. European Biochar Certificate-Guidelines for Sustainable Production of Biochar. European Biochar Foundation; EBC: Arbaz, Switzerland, 2012. Available online: http:/ / www.european-biochar.org/en/download (accessed on 30 August 2018). [CrossRef]

88. Srinivasan, P.; Sarmah, A.K.; Smernik, R.; Das, O.; Farid, M.; Gao, W. A feasibility study of agricultural and sewage biomass as biochar, bioenergy and biocomposite feedstock: Production, characterization and potential application. Sci. Total Environ. 2015, 512, 495-505. [CrossRef]

89. Zhang, J.; Lu, F.; Zhang, H.; Shao, L.; Chen, D.; He, P. Multiscale visualization of the structural and characteristic changes of sewage sludge biochar oriented towards potential agronomic and environmental implication. Sci. Rep. 2015, 5, 9406. [CrossRef]

90. Lee, J.Y.; Lee, K.K. A short note on investigation and remediation of contaminated groundwater and soil in Korea. J. Eng. Geol. 2004, 14, 123-130.

91. Molenda, J.; Swat, M.; Osuch-Słomka, E. Effects of thermal conditions of pyrolysis process on the quality of biochar obtained from vegetable waste. Eng. Prot. Environ. 2018, 21, 289-302. [CrossRef]

92. Schulzki, G.; Nublein, B.; Sievers, H. Transition rates of selected metals determined in various types of teas (Camellia sinensis L. Kuntze) and herbal/fruit infusions. Food Chem. 2017, 215, 22-30. [CrossRef]

93. Hu, X.; Guo, H.; Gholizadeh, M.; Sattari, B.; Liu, Q. Pyrolysis of different wood species: Impacts of C/H ratio in feedstock on distribution of pyrolysis products. Biomass Bioenergy 2019, 120, 28-39. [CrossRef] 